\title{
El constitucionalismo español y portugués durante la primera mitad del siglo XIX (un estudio comparado)
}

\author{
JOAQUÍN VARELA SUANZES-CARPEGNA*
}

\begin{abstract}
Resumo: O artigo examina o desenvolvimento do processo constitucional na Península Ibérica desde os primeiros momentos em que o movimento liberal ganha força. $\mathrm{Na}$ Espanha, as Cortes reunidas em Cádiz conseguem promulgar, em 1812, uma Constituição que passará a ser um importante modelo para os revolucionários de então. Já em Portugal, a revolução constitucional chega logo depois da restauração liberal espanhola, em 1820, inaugurando uma nova era. Segue-se o estudo dos avanços e das vicissitudes do constitucionalismo peninsular durante toda a primeira metade do século XIX.

Abstract: This article examines the development of the constitutional process at the Iberian Peninsula since the first moments, when the legal movement gains force. In Spain the united court in Cadiz succeed to promulgate in 1812 a Constitution, which turns out to be an important model for the revolutionaries at that time. In Portugal the constitutional revolution arrives shortly after the Spanish liberal restoration in 1820 inaugurating a new era. It follows the study of the progress and vicissitudes of the constitutionalism peninsular during the first half of the 19th century.
\end{abstract}

Palavras-chave: Constitucionalismo ibérico. Liberalismo. Revoluções liberais.

Key words: Iberian constitucionalism. Liberalism. Liberal revolutions.

\author{
"O frade era, até certo ponto, \\ o Dom Quixote da sociedade Velha. \\ O barão é, em quase todos os pontos, \\ o Sancho Pança da sociedade nova". \\ Almeida Garret, Viagens na minha terra, \\ 1843, cap. XIII.
}

\footnotetext{
* Catedrático de Derecho Constitucional, Universidad de Oviedo, España.
}

Estudos Ibero-Americanos. PUCRS, v. XXXIII, n. 1, p. 38-85, junho 2007 


\section{Introducción}

En las páginas que siguen voy a reflexionar sobre la evolución del constitucionalismo español y portugués a lo largo de la primera mitad del siglo XIX, con el propósito primordial de mostrar sus semejanzas, sus diferencias y sus mutuas influencias en el plano de los hechos, de las ideas y sobre todo de los textos constitucionales. ${ }^{1}$ Ahora bien, para ello no basta con cotejar los dos constitucionalismos ibéricos, sino que es preciso insertarlos en el contexto más amplio de la historia constitucional comparada, con particular referencia a la británica y a la francesa. Una perspectiva sin duda más compleja y quizá por ello poco frecuente en la historiografía española y portuguesa, que ni siquiera suele analizar los dos constitucionalismos ibéricos desde un punto de vista bilateral.

De acuerdo con estas premisas, en estas páginas me voy a centrar en el examen del modelo constitucional establecido en la Constitución española de 1812 y en la portuguesa de 1822, inspirado en la filosofía política de la Revolución francesa de 1789, y en su sustitución por otro modelo más conservador, cuya principal fuente de inspiración era el constitucionalismo que se había desarrollado en la Gran Bretaña desde la revolución inglesa de 1688, que en la Francia post-napoleónica difundieron Benjamín Constant y los doctrinarios Guizot y Royer-Collard, las autoridades más influyentes de los liberales ibéricos durante los años treinta y cuarenta del siglo XIX, junto a Jeremy Bentham.

Con el primer modelo constitucional los "doceañistas" españoles y los "vintistas" portugueses pretendieron construir, como había ocurrido en Francia entre 1789 y 1792, una monarquía asamblearia, en la que unas Cortes unicamerales, elegidas mediante un sufragio muy amplio, debían convertirse en el órgano más relevante dentro de ese nuevo Estado, al que debía subordinarse el monarca. Con el segundo modelo constitucional se vertebró en la Península Ibérica una monarquía constitucional que atribuía la dirección política del Estado a la Corona y, en menor medida, a unas Cortes compuestas de dos Cámaras: la Alta, en la que tenían asiento la nobleza, el Clero y los altos cuerpos de la Administración, y la Baja, elegida a través de un sufragio censitario.

Este último modelo constitucional tuvo en las dos naciones ibéricas dos versiones: la más conservadora de ellas, alentada por

1 O presente texto foi apresentado como conferência no VI Congresso Internacional de Estudos Ibero-Americanos, realizado pelo Programa de Pós-Graduação em História da Pontifícia Universidade Católica do Rio Grande do Sul, em outubro de 2006 (N. E.). 
los “cartistas" portugueses y los "moderados” españoles (también por Gran Bretaña y Francia, las dos potencias europeas hegemónicas, sin cuya influencia política y económica no se entiende la historia peninsular de este período), tuvo su reflejo en la Carta de 1826, que serviría de cimiento a la monarquía constitucional portuguesa del siglo XIX; mientras que en España cristalizó, primero, en el muy incompleto Estatuto Real de 1834 y, más tarde, en la Constitución de 1845. Una versión menos conservadora, pero alejada también de los esquemas revolucionarios del "doceañismo" y del "vintismo", se plasmó en la Constitución española de 1837, alentada por los "progresistas", y en la portuguesa de 1838, el fruto más preciado del movimiento "septembrista".

Si el sub-modelo "cartista"/"moderado" se inspiraba sobre todo en la Carta francesa de 1814; el "progresista"/"septembrista" lo hizo de forma primordial en la Carta francesa de 1830 y en la Constitución belga de 1831, pero en ambos casos, como queda dicho, se trataba de adaptar a la Península ibérica el constitucionalismo británico que se había desarrollado desde 1688, ya fuese desde los esquemas de la monarquía constitucional (los preferidos por los "cartistas" y los "moderados") o desde los mas avanzados (por los que se inclinaban los "progresistas" y los "septembristas") de la monarquía parlamentaria, tal como se habían ido desarrollando en la Gran Bretaña desde el reinado de Jorge I, a principios del setecientos, con dos hitos fundamentales: la dimisión de Lord Norh en 1782 y la Ley de Reforma de 1832.

\section{2 "Doceñismo" y "Vintismo" - las constituciones de 1812 y 1822}

\subsection{El liberalismo doceañista y la Constitución de Cádiz}

\subsubsection{Afrancesados y patriotas}

Conviene subrayar que el factor que desencadenó el nacimiento del constitucionalismo español fue exógeno, no endógeno: la invasión francesa. Este es un hecho notable, que debe tenerse en cuenta para comprender el alcance y las limitaciones de la revolución española. Desde luego, las ideas constitucionales habían empezado a difundirse entre la élite intelectual desde la segunda mitad del siglo XVIII, pero sólo tras la invasión francesa comienza a construirse en España un Estado constitucional. 
La secuencia de los hechos es bien conocida, pero conviene recordarla. Entre los días 17 y 19 de marzo de 1808 tuvo lugar el llamado "motín de Aranjuez", a resultas del cual Carlos IV se vio obligado a abdicar la Corona en su hijo Fernando VII y a exonerar a su Primer Ministro, Godoy. Una semana después, las tropas de Napoleón, con el pretexto de dirigirse a Portugal y al amparo del Tratado de Fontenebleau, que ambas naciones habían suscrito el año anterior, entran en Madrid, al mando de Murat. El 10 de abril, Fernando VII decide salir de Madrid, acompañado de sus más íntimos colaboradores, para encontrarse con el Emperador de los franceses, con la intención de que Napoleón le reconociese como legítimo rey de España. Diez días más tarde Fernando VII llega a la ciudad francesa de Bayona, mientras que sus padres, Carlos IV y María Luisa, lo hacen diez días el 30 de abril, con la pretensión de que Napoleón obligue a Fernando VII a devolver a su padre la Corona de España. Pero el Emperador, que hábilmente había conseguido engañar tanto a Fernando VII como a Carlos IV, llevando a Bayona a la familia real española, no pretendía otra cosa que la renuncia de todos los Borbones a la Corona española. Un objetivo que consiguió a principios de mayo, lo que le permitió dos meses más tarde que su hermano José fuese reconocido como rey de España y de las Indias.

Con las renuncias de Bayona se desplomó la monarquía hispánica y se produjo una profunda crisis en la sociedad española, la más importante de toda su historia contemporánea hasta la de 1936. Es preciso tener en cuenta que poco antes de que se formalizasen dichas renuncias, exactamente el 2 de mayo, el pueblo de Madrid se alzó en armas contra las tropas francesas que ocupaban la ciudad. Este alzamiento fue duramente reprimido por las tropas de Murat, lo que provocó el levantamiento general en toda España $\mathrm{y}$, en realidad, el comienzo tanto de una dura y larga Guerra de Independencia y de una auténtica revolución liberal, con la que se inició el constitucionalismo en nuestro país.

Para hacer frente a la crisis abierta por las renuncias de Bayona, algunos españoles decidieron pactar con los invasores y aceptar la legitimidad de José I. Esta fue la opción por la que se decantaron los afrancesados muchos de los cuales ocupaban una alta posición social, política e intelectual. Los afrancesados compartían, además, los principios políticos del despotismo ilustrado. Eran hombres de talante moderado, contrarios a cualquier veleidad revolucionaria. Frente al principio de soberanía nacional, invocado por los patriotas liberales en las Cortes de Cádiz para justificar la sublevación contra Napoleón, los afrancesados se escudaron en el 
principio monárquico, lo que les permitió fundamentar doctrinalmente su lealtad a José I, en cuya monarquía autoritaria veían, además, un necesario instrumento de modernización política, sin los peligros que la revolución liberal comportaba. El texto que recogió las líneas maestras de esta monarquía fue el Estatuto de Bayona, en realidad impuesto por Napoleón a una Junta de notables reunidos en esa ciudad francesa y formalmente aprobado por su hermano José I el 6 de julio de 1808. Este texto se inspiraba en el principio monárquico, que se recogía de forma explícita en el encabezamiento, a partir del cual se otorgaba la dirección política del Estado al monarca, articulándose las Cortes como un órgano representativo-estamental. A pesar de su carácter autoritario, el Estatuto de Bayona reconocía, de forma dispersa, un conjunto de principios y libertades claramente enraizados en el nuevo orden liberal-burgués, como la libertad de imprenta, la libertad personal, la igualdad fiscal y de fueros, la inviolabilidad de domicilio, la supresión de privilegios y el acceso a los cargos públicos conforme al mérito y a la capacidad.

El artículo 143 del Estatuto ordenaba su gradual entrada en vigor a través de decretos o edictos del rey, que no llegaron a aprobarse, por lo que puede decirse que este texto no estuvo nunca plenamente vigente en la España ocupada por los franceses. A medida que las tropas francesas fueron siendo derrotadas, cosa que ocurrió sobre todo tras la batalla de Bailén, y el territorio español liberado, se fue reduciendo todavía más el territorio y la población sobre la que este texto debía aplicarse.

Los españoles que prefirieron dar una alternativa constitucional "patriótica" a la crisis provocada por la invasión francesa, reconocieron a Fernando VII como legítimo rey de España y negaron validez a las renuncias de Bayona, por haberse llevado a cabo mediante el engaño y, para los liberales, por no haber contando con el consentimiento de la nación. Por todo el país se fueron articulando Juntas Provinciales, que se autoproclamaron soberanas y que disputaron el poder al Consejo de Castilla y a la Junta de Gobierno, las dos más relevantes instituciones del Antiguo Régimen. Con el objeto de coordinar la dirección política y la resistencia militar - esta última protagonizada tanto por ejército regular español, reforzado con la ayuda británica, como por las guerrillas populares - las Juntas Provinciales decidieron crear una Junta Central, compuesta de treinta y cinco miembros, la mayoría de ellos nobles, que se puso en planta el veinticinco de septiembre de 1808, en Aranjuez, bajo la presidencia del viejo conde de Floridablanca. En diciembre de ese año la Central se trasladó a Sevilla, que se convir- 
tió en la capital de la España no ocupada por los franceses. Todos sus miembros estaban de acuerdo en convocar las Cortes, aunque discrepaban sobre la estructura, la composición y el alcance de sus poderes, asunto sobre el que debatieron a lo largo de 1809. Pese a que el influyente das por Jovellanos se manifestó a favor de unas Cortes estamentales, circunscritas a "mejorar" las leyes fundamentales de la monarquía o "constitución histórica de España", al final triunfaron los partidarios de convocar unas Cortes unicamerales y con poderes constituyentes. El 31 de enero de 1810, una vez convocadas las Cortes, la Junta Central decidió autodisolverse, no sin antes crear un Consejo de Regencia, al que un decreto de 31 de enero transfería toda la "autoridad" y "poder" de la Junta Central, "sin limitación alguna".

\subsubsection{Las Cortes de Cádiz}

Las Cortes se reunieron por vez primera el 24 de septiembre de 1810, en la ciudad de Cádiz, una de las más liberales de España. No se sabe con exactitud el número de diputados elegidos. Pero puede decirse que fueron alrededor de trescientos. Aunque lo más probable es que nunca llegasen a estar todos juntos. Un tercio de ellos pertenecía a los estratos más elevados del clero. Abundaban también los juristas, unos sesenta, y los funcionarios públicos, entre los que sobresalían dieciseis Catedráticos. Una treintena larga eran militares y ocho eran títulos del reino. Había quince propietarios, cinco comerciantes, cuatro escritores, dos médicos y cinco marinos.

En estas Cortes no puede hablarse todavía de partidos políticos, pues faltaba la organización necesaria para ello. Pero sí es posible y necesario hablar de "tendencias constitucionales", esto es, de grupos de diputados unidos entre sí por una común, aunque no idéntica, filiación doctrinal. A este respecto, dentro de estas Cortes se distinguían tres tendencias constitucionales. En primer lugar, la que formaban los Diputados realistas, cuyas tesis ponían de relieve una mezcla de escolasticismo e historicismo nacionalista, que se concretó en la defensa de la doctrina suareziana de la translatio imperii y de la soberanía compartida entre el rey y las Cortes, así como en la necesidad de que éstas respetasen la "esencia" de las leyes fundamentales de la monarquía o Constitución histórica de España a la hora de redactar el texto constitucional, como había defendido Jovellanos en el seno de la Junta Central. Los diputados realistas criticaron tanto el pensamiento revolucionario francés como las doctrinas 
absolutistas: ni revolución ni reacción, reforma de lo existente, vendría a ser su lema, aunque no pocos de ellos, como Inguanzo, estaban muy alejados del talante ilustrado de Jovellanos, como se puso de relieve sobre todo en el debate de la Inquisición.

La segunda tendencia estaba formada por los diputados liberales, cuyos principios constitucionales eran básicamente los mismos que habían defendido los "patriotas" franceses en la Asamblea de 1789, en particular la soberanía nacional y una concepción de la división de poderes destinada a convertir las Cortes unicamerales en el centro del nuevo Estado, aunque tales principios los defendiesen con un lenguaje muy distinto. Así, en efecto, aunque no faltaron referencias a los lugares comunes del iusnaturalismo racionalista (estado de naturaleza, pacto social, derechos naturales, etc.), por parte de algunos diputados liberales, como Toreno, la mayoría de ellos prefirió justificar sus tesis incluidas la soberanía nacional y la división de poderes acudiendo a un supuesto liberalismo medieval español. En realidad, en la apelación a la Edad Media para justificar sus tesis coincidían realistas y liberales, si bien los primeros, siguiendo a Jovellanos, deformaban mucho menos la realidad histórica que los segundos, más próximos a las tesis que defendería Francisco Martínez Marina en la "Teoría de las Cortes".

Los diputados americanos formaban la tercera tendencia constitucional. Es preciso tener en cuenta que la invasión francesa de 1808 había dado lugar en los vastos territorios de la América española a los inicios de un proceso emancipador que culminaría noventa años más tarde con la independencia de Cuba, Puerto Rico y Filipinas. Pero una parte de las elites criollas seguía apostando por mantener los lazos con la Madre Patria, aunque a través de una Constitución que tuviese en cuenta el autogobierno de las provincias de ultramar y que diesen una justa representación a la población americana en los órganos del Estado constitucional en ciernes, sobre todo en las Cortes. En ambos puntos estaban de acuerdo todos los americanos presentes en la Asamblea gaditana, en cuyas premisas constitucionales se mezclaban principios procedentes de la neoescolástica española y del derecho de Indias con principios revolucionarios, por ejemplo de Rousseau, a lo que debe añadirse el influjo del iusnaturalismo germánico, sobre todo de Grozio y Puffendorff.

Pero junto a la filiación doctrinal es preciso decir unas palabras sobre los modelos constitucionales por los que se decantaron cada una de estas tres tendencias. Los diputados realistas mostraron sus simpatías por el constitucionalismo inglés o, con más exactitud, por 
la versión que de éste había dado Montesquieu. Ahora bien, lo que cautivó a los realistas no fue la posición constitucional del monarca británico, sino la organización de su Parlamento. A este respecto, trajeron a colación la teoría de los cuerpos intermedios, acuñada por el autor del Espíritu de las Leyes, e insistieron no tanto en la importancia de un ejecutivo monárquico fuerte al estilo del británico, cuanto en la necesidad de una representación especial para la nobleza y sobre todo para el clero, estamento al que pertenecía buena parte de los realistas. Una representación especial, similar a la Cámara de los Lores, que Jovellanos había defendido en su Memoria en Defensa de la Junta Central.

Los diputados liberales tenían en alta estima ciertos aspectos del constitucionalismo británico, como el Jurado y la libertad de Imprenta, pero había algunos rasgos de este modelo que les desagradaban, como la extensión de la prerrogativa regia y el carácter aristocrático de la Cámara de los Lores. Estos Diputados no eran, pues, propiamente anglófilos, a diferencia de Jovellanos y de Ángel de la Vega Infanzón, quienes desde la invasión francesa habían intentado introducir en España una monarquía similar a la británica, de acuerdo en gran medida con las sugerencias de Lord Holland y de su íntimo amigo y colaborador el Doctor Allen. En realidad, las ideas nucleares de los diputados liberales procedían del iusnaturalismo racionalista (Locke, Rousseau), de Montesquieu y en general de la cultura enciclopedista (Voltaire, Diderot). Esta influencia foránea se mezcló con la del historicismo medievalizante y, en algún caso, como el de los clérigos Muñoz Torrero y Espiga, con el de la neoescolástica española, mientras que tan sólo en Argüelles se detecta el eco del positivismo de Bentham. No resulta extraño, por todo ello, que el modelo más influyente entre los liberales doceañistas fuese el que se había vertebrado en Francia a partir de la declaración de derechos de 1789 y de la Constitución de 1791. Un texto este último que se tuvo muy en cuenta a la hora de redactar la Constitución española de 1812, aunque entre ambos códigos haya notables diferencias, como luego se verá.

A los diputados americanos no les satisfacía, en cambio, ni el modelo constitucional británico ni el francés de 1791. El primero era incompatible con su mentalidad anti-aristocrática, proclive a un igualitarismo que rebasaba los límites del primigenio liberalismo; el segundo, inspirado en el dogma jacobino de la soberanía nacional, no les agradaba por su radical uniformismo político y administrativo. En realidad, los diputados americanos parecían mirar más hacia la monarquía cuasi-federal de los Habsburgos arrumbada por el centralismo borbónico - que hacia los modelos 
constitucionales entonces vigentes. De escoger uno de entre éstos, acaso sus simpatías se inclinasen por el de los Estados Unidos. Un modelo que no convencía en absoluto ni a los realistas ni a los liberales. A los primeros, sobre todo por su republicanismo; a los segundos, cuyo jacobinismo era notable, primordialmente por su federalismo, expresamente rechazado en aquellas Cortes.

\subsubsection{La Constitución de 1812}

La Constitución de Cádiz se componía de trescientos ochenta y cuatro artículos y venía precedida de un extenso discurso preliminar, redactado sobre todo por Agustín Argüelles y en el que se aseveraba que las bases del proyecto de Constitución, lejos de consagrar novedades importadas, habían sido "para nuestros mayores verdaderas prácticas, axiomas reconocidos y santificados por las costumbres de muchos siglos".

Los dos principios básicos de la Constitución de Cádiz eran el de soberanía nacional y el de división de poderes, proclamados ya el decreto de 24 de septiembre de 1810, el primero que aprobó las Cortes nada más abrir sus sesiones. El principio de soberanía nacional se recogía en el artículo tercero del texto constitucional, que decía así: "la soberanía reside esencialmente en la nación, y por lo mismo le pertenece exclusivamente el derecho de establecer sus leyes fundamentales y la forma de gobierno que más le convenga", inciso este último que, tras el debate, se suprimió. A tenor de este principio, el título $X$ del código doceañista organizaba un procedimiento especial para revisar la Constitución, distinto del legislativo ordinario y del que se excluía al monarca. De tal forma que si la Constitución de Cádiz se aprobó sin la sanción regia - ni siquiera se dio oportunidad a la Regencia para que la sancionase en nombre del rey ausente tampoco se permitía que en el futuro el monarca sancionase - o se negase a hacerlo - la Constitución que las Cortes Constituyentes habían aprobado.

El principio de división de poderes transformaba también radicalmente la vieja monarquía española. El rey ya no ejercería en adelante todas las funciones del Estado. Es verdad que la Constitución le seguía atribuyendo en exclusiva el ejercicio del poder ejecutivo, le confería una participación en la función legislativa a través de la sanción de las leyes y proclamaba que la Justicia se administraba en su nombre. No obstante, en adelante serían las Cortes el órgano supremo del Estado. Un órgano que se componía de una sola cámara, cuyos miembros se elegían a través de un sufragio indirecto, a tres grados, que confería la capacidad 
electoral activa y pasiva a buena parte de los varones mayores de edad, con exclusión de los sirvientes domésticos, las mujeres y las "castas" americanas. Las Cortes desempeñarían la función legislativa, pues el monarca sólo podría interponer un veto suspensivo a las leyes aprobadas en Cortes, que sólo podía retrasar su entrada en vigor. Además, en las Cortes recaía de forma primordial, aunque no exclusiva, la dirección de la política en el nuevo Estado por ellas diseñado, sobre todo en lo que concierne a las relaciones internacionales y a las fuerzas armadas, pese a las competencias del rey en estos ámbitos.

Las relaciones entre las Cortes y el rey se regulaban de acuerdo con unas premisas muy similares a las que habían sustentado los "patriotas" franceses en la Asamblea de 1789, en las que se reflejaba la gran desconfianza del liberalismo revolucionario hacia el ejecutivo monárquico. Para citar tan sólo dos ejemplos, la Constitución prohibía al rey la disolución de las Cortes e impedía que los secretarios de Estado - todavía no se hablaba de "ministros" ni de "Gobierno" como órgano colegiado - fuesen a la vez diputados, en abierta oposición al sistema parlamentario de gobierno, ya muy afianzado entonces en la Gran Bretaña, que había defendido Mirabeau en la Asamblea de1789 y Blanco-White desde las páginas de "El Español". Por último, la Constitución de Cádiz cambiaba también de forma radical el ejercicio de la función jurisdiccional, que atribuía a unos jueces y magistrados independientes. Era ésta una básica premisa liberal cuya defensa hacía el discurso preliminar conectándola con la salvaguardia de la libertad y la seguridad personales, de acuerdo con lo que habían dicho Locke y Montesquieu.

El código doceañista carecía de una declaración de derechos, aunque su artículo cuarto, de claro sabor lockeano, señalaba que la nación estaba "obligada a conservar y proteger por leyes sabias y justas la libertad civil, la propiedad, y los demás derechos legítimos de todos los individuos que la componen". Por otro lado, el título V de esta Constitución, "De los Tribunales y de la Administración de Justicia”, reconocía algunas garantías procesales estrechamente conectadas a la seguridad personal, como el derecho al juez predeterminado por la ley (art. 247), el derecho a dirimir contiendas por medio de jueces árbitros (art. 280), el derecho de habeas corpus (art. 287 en relación con los arts. 290, 293 y 300), la prohibición de tormento (art. 303) y la inviolabilidad de domicilio (art. 306), mientras que el artículo 371 reconocía a todos los españoles la "libertad de escribir, imprimir o publicar sus ideas políticas sin necesidad de licencia, revisión o aprobación alguna anterior a la 
publicación". Otros preceptos sancionaban la igualdad de todos los españoles ante la ley: igualdad de fueros (arts. 248 y 258) así como, ya fuera del Título $\mathrm{V}$, igualdad en el cumplimiento de las obligaciones fiscales (arts. 8 y 339). Por su parte, el art. 373 reconocía el derecho de petición. Pero un derecho de tanta importancia como el de libertad religiosa, admitido en el constitucionalismo inglés, americano y francés, no aparecía por parte alguna en el código español de 1812. Antes al contrario, el artículo 12 de este texto consagraba la confesionalidad católica del Estado de manera rotunda: "la religión de la nación española - decía este precepto es y será perpetuamente la católica, apostólica, romana, única verdadera. La Nación la protege por leyes sabias y justas, y prohíbe el ejercicio de cualquier otra". Este precepto, aprobado sin rechistar por los diputados liberales, era una dolorosa concesión de estos Diputados - incluidos los de clerical condición - a los realistas y, en realidad, a los sentimientos mayoritarios de los españoles. Es preciso tener en cuenta que el preámbulo de la Constitución, además de reiterar el engarce de la Constitución con los viejos códigos de la monarquía medieval española, invocaba a "Dios todopoderoso, Padre, Hijo y Espíritu Santo", como "Autor y Supremo Legislador de la Sociedad". En realidad, todo el texto de esta Constitución estaba impregnado de un fuerte matiz religioso. Eso no quiere decir que los liberales doceañistas compartiesen esta mixtura de religión y política, ni mucho menos la intolerancia religiosa. Es muy necesario a este respecto, distinguir entre el liberalismo doceañista y la Constitución de Cádiz, pues en este texto no se reflejó todo lo que aquellos pretendieron, como la tolerancia religiosa.

La Constitución de Cádiz apenas se pudo poner en vigor, pues en mayo de 1814 Fernando VII, de vuelta de su exilio francés, la derogó, junto a todos los demás decretos aprobados por las Cortes. Comenzaba, así, un sexenio absolutista. La primera experiencia constitucional española se había saldado con un fracaso. No había contado con el apoyo del pueblo y había concitado, en cambio, la hostilidad de buena parte de la nobleza y del clero. 


\subsubsection{El Trienio Constitucional}

Pero el absolutismo tampoco duraría mucho. Tras los intentos fallidos de Mina, Porlier, Richard, Renovales y Lacy de acabar con él por la fuerza, el 1 de enero de 1820 el Pronunciamiento de Riego logró tan ansiado objetivo. La caída del absolutismo trajo consigo el restablecimiento de la Constitución de Cádiz. Fernando VII, que tanto la odiaba, se vio obligado a acatarla el 10 de marzo de ese año. Pero lejos de sus promesas de fidelidad a este código, comenzó a conspirar contra él al poco de ser restaurado, para lo que no dudó en recabar la colaboración de la Santa Alianza, integrada por Rusia, Austria, Prusia y Francia. Unas naciones que no podían ver con buenos ojos un código tan revolucionario como el doceañista, que tampoco agradaba demasiado al Gobierno tory de Lord Liverpool. La Gran Bretaña, en realidad, no tenía demasiado interés en que se consolidase el Estado Constitucional español, no tanto por prejuicios ideológicos cuanto porque la inestabilidad política de España favorecía la emancipación de la América hispana. Un vasto territorio codiciado por el comercio británico, aunque los Estados Unidos no estaban dispuestos a permitir que en aquel hemisferio volviesen a ondear las enseñas de ninguna nación europea, como advertiría con toda claridad el Presidente Monroe en 1823. Ni a la Santa Alianza ni a la Gran Bretaña podían complacer tampoco la admiración que suscitaba el texto doceañista fuera de España. En Portugal - como se verá con más detalle más adelante -, en Nápoles y en el Piamonte, en efecto, la Constitución de Cádiz no tardaría en adoptarse como bandera propia, al igual que años más tarde harían los decembristas rusos. En realidad, la promulgación de este texto constitucional en 1820 supuso una luz de esperanza para los liberales radicales y para los demócratas de toda Europa, relegados o perseguidos a consecuencia de la política reaccionaria que la Santa Alianza había impuesto en el viejo continente. La Constitución de 1812 se convirtió, así, durante el Trienio en un punto de referencia para todo el movimiento liberal y nacionalista de Europa y América, marcando un hito decisivo en la historia del liberalismo occidental.

Pero la hostilidad de Fernando VII al nuevo régimen constitucional y el contexto internacional tan poco favorable para el asentamiento de este régimen en España no bastan para explicar el fracaso del Trienio. Es preciso tener en cuenta también la división del liberalismo español entre "exaltados" y "moderados", que resultó funesta para la supervivencia del nuevo régimen y que se puso de manifiesto a comienzos de 1820 con motivo de la disoluci- 
ón del "Ejército de la Isla", esto es, del contingente de tropas mandadas por los héroes de la revolución: Rafael de Riego, en un primerísimo lugar, Quiroga, Arco-Agüero y López Baños. Los "exaltados" querían hacer de este Ejército un bastión armado de la revolución, oponiéndose a que fuese disuelto. Los "moderados" temían, en cambio, el papel que este Ejército podía jugar como grupo de presión frente a las Cortes y al Gobierno. De ahí su interés en disolverlo, que fue a la postre lo que ocurrió. Pero junto a esta cuestión hubo otras muchas que a lo largo de estos tres años dividieron a los liberales españoles, como el nombramiento de altos cargos de la Administración civil y militar, la legalización de las Sociedades Patrióticas y, sobre todo, la estrategia que debía seguir el proceso de transformación social en España. Los "exaltados" cuyas premisas estaban a caballo del liberalismo y del jacobinismo, apelando unas veces a las libertades individuales y otras a los derechos del pueblo - querían restablecer íntegramente el programa de las Cortes de Cádiz e incluso radicalizarlo. Uno de sus dirigentes más destacados era Flórez Estrada, además de Romero Alpuente, Moreno Guerra, Istúriz y Calvo de Rozas. Los “exaltados” pensaban que había un peligroso divorcio entre el poder político y el poder social, que sólo podía solucionarse acelerando el proceso revolucionario y ampliando la base social de las nuevas instituciones, aunque en aquel entonces centrasen sus expectativas en las clases populares urbanas - de ahí su hincapié en las milicias populares y en las Sociedades Patrióticas - pero no en el campesinado, que representaba la inmensa mayoría de la población española. Los "moderados" pensaban, por el contrario, que no debían radicalizarse los conflictos entre las fuerzas del Antiguo Régimen y las favorables al nuevo orden liberal, sino buscar un entendimiento entre éstas y las más contemporizadoras de aquéllas, teniendo en cuenta, precisamente, el escaso apoyo popular con que contaba el Estado constitucional, que se había puesto de manifiesto de forma trágica en 1814, cuando la masa popular había dado la bienvenida al absolutismo. Entre sus miembros más preeminentes figuraban muchos liberales que habían tenido una sobresaliente participación en las Cortes de Cádiz, como Argüelles, Toreno, Muñoz Torrero y Espiga. Si los "exaltados" acusaban a los "moderados" de ser demasiado condescendientes con las fuerzas reaccionarias y de intentar beneficiarse en su exclusivo provecho del ejercicio del poder, éstos se defendían acusando a aquéllos de favorecer objetivamente el desmoronamiento del régimen y de concitar la inquina del Monarca, de buena parte de la Aristocracia y del Clero, así como de la Santa Alianza. 
No puede decirse, en cambio, que la existencia misma de la Constitución de 1812 fuese un punto que dividiese a los "moderados" y "exaltados", al menos abiertamente. De hecho, durante el Trienio no llegó a proponerse nunca en las Cortes su reforma. En cualquier caso, muchos "moderados", como el Conde de Toreno, se habían distanciado ya de este código incluso antes del Pronunciamiento de 1820, mientras que otros se irían alejando de él a lo largo del Trienio. Por otro lado, no pocos "exaltados", aunque quizá no la mayoría, eran conscientes también de que el código doceañista no era el más adecuado para la España de entonces. Los constantes conflictos entre el rey y sus ministros y entre éstos y las Cortes contribuyeron a que buena parte de los liberales españoles, sobre todo los más conservadores, pero no sólo ellos, se fuese alejando del modelo doceañista y buscase otro más eficaz para edificar el Estado constitucional y más acorde también con los nuevos vientos que soplaban en Europa.

Lo que con claridad meridiana se puso de manifiesto durante el Trienio era que el sistema de gobierno sólo podía funcionar bajo la Constitución de Cádiz si el Ejecutivo (rey y ministros) y las Cortes coincidían en la dirección política del Estado. De no ser así el colapso del sistema estaba asegurado. Un colapso, además, irremediable en el marco de la legalidad doceañista, puesto que en España, como antes en Francia, a la cúspide del poder ejecutivo se accedía de forma hereditaria y vitalicia, a diferencia de lo que ocurría en los Estados Unidos de América. Ante esta grave tesitura, que se puso en evidencia de forma dramática desde los primeros meses del Trienio, los liberales sólo podían adoptar dos soluciones (para los absolutistas estaba claro desde el principio que la única solución era acabar pura y simplemente con el Estado constitucional): la primera, por la que se inclinaron los "exaltados", era la de deslizar al Estado hacia un sendero asambleario, acelerando las transformaciones económicas y sociales que hiciesen posible un auténtico liberalismo popular- verdadera contradictio in terminis en la España de entonces y en general en la del siglo XIX -, capaz de hacer frente a los poderosos enemigos interiores y exteriores, infringiendo si era preciso la Constitución o, al menos, interpretándola de acuerdo con las premisas del sistema asambleario de gobierno. La segunda solución - que parecía imponerse a medida que la exégesis presidencialista de la Constitución de Cádiz iba siendo derrotada - era la de abandonar el modelo monárquico vertebrado en esta Constitución y articular otro modelo inspirado en el constitucionalismo británico. Esta solución fue la que se impondrían en España después de la muerte de Fernando VII. 
Pero, de momento, lo que triunfó en 1823 fue el restablecimiento del absolutismo fernandino de la mano del duque de Angulema, sobrino de Luis XVIII, y de sus "Cien mil hijos de San Luis", que comenzaron a ocupar España en la primavera del 1823. La intervención francesa había sido decidida en el otoño de 1822 por las Cancillerías de Austria, Prusia, Rusia, Francia, las Dos Sicilias y Módena, reunidas en el Congreso de Verona, con el disentimiento de Inglaterra, representada en aquel Congreso por Canning, quien desde el verano de 1822 se encontraba al frente del Foreign Office, tras el suicidio de Castlereagh. En Francia la intervención militar había dado lugar a acalorados debates en las dos Cámaras del Parlamento. Los doctrinarios se opusieron a ella, pero los "ultras", que contaban con la mayoría después de las elecciones de 1821, la apoyaron. Chateaubriand- Ministro de Asuntos de Exteriores en el Gobierno Villčle - fue el más ardoroso defensor de la intervención francesa, al ver en ella una magnífica oportunidad para resarcir el honor del ejército francés después de la derrota que diez ańos antes le había infligido el pueblo español

\subsection{El liberalismo "vintista” y la Constitución de 1822}

\subsubsection{Liberalismo y nacionalismo}

En Portugal, como en España, las nuevas ideas enciclopedistas e incluso liberales, junto a las novedades científicas, se habían ido difundiendo durante el último tercio del siglo XVIII, en buena medida gracias a la reforma de la enseñanza emprendidas por el marqués de Pombal, de acuerdo con lo que había sustentado años antes el más notable de todos los estrangeirados, Luís Verney, en el "Verdadeiro Método de Estudos" (1747). Unas reformas no muy distintas a las que llevaron a cabo en España Campomanes y Olavide. Pero sin desdeñar estos antecedentes, no cabe duda de que el triunfo del primer liberalismo en Portugal está ligado de forma inseparable a la lucha por la independencia nacional y en contra de la presencia extranjera, pero no a la francesa, como en la España de 1808, sino a la británica. Recordemos a este respecto algunos hechos.

El 27 de noviembre de 1807, antes de que las tropas francesas ocupasen el territorio portugués, al amparo del tratado de Fontenebleau, que preveía el reparto de Portugal entre Francia y España, el futuro Juan VI, entonces príncipe regente de Portugal, siguiendo los consejos británicos y bajo la protección de la Armada 
de Jorge III, decidió trasladarse a Rio de Janeiro con toda la familia real, incluida su madre, la Reina Maria I, dejando al frente del país un Consejo de Regencia. Acompañaban a la familia real un séquito de diez mil hombres, entren los que se encontraban la casi totalidad de los altos cargos de la Administración del Estado, muchos nobles y algunos ricos comerciantes. Brasil se convirtió, así, de súbito en la capital de un imperio, hasta el regreso de Juan VI a Lisboa, el 3 de junio de 1821, ya como rey, al haber muerto su madre cinco años antes. Portugal, pues, estuvo casi catorce años sin rey, en lugar de los seis que había estado España. Esta ausencia del monarca va a tener un influjo muy notable en los orígenes del constitucionalismo ibérico y en gran medida explica su radicalismo.

A finales de 1807, el General Junot atravesó España y ocupó Portugal. Su presencia fue bien recibida por algunas elites ilustradas y liberales, que incluso le presentaron un proyecto de Constitución, atribuido a Fernando Duarte Coelho, en el que se pretendía crear un monarquía constitucional portuguesa, en el marco del imperio napoleónico. Sin embargo, este proyecto no llegó a aprobarse, a diferencia de lo que había ocurrido en España con el Estatuto de Bayona. La presencia de las tropas francesas fue rechazada por la mayoría de la población, como ocurriría más tarde con las invasiones de Soult, en 1808, y del Mariscal Massena, en 1810 y 1811. En Portugal, sin embargo, no hubo una resistencia guerrillera tan importante como en España, ni tampoco nada parecido a un movimiento juntista capaz de articular un nuevo Estado y de convocar Cortes. El peso de la resistencia recayó en la alianza entre los ejércitos portugués y británico, que lograron expulsar definitivamente a los franceses en 1811. Pero debido a que el Estado estaba descabezado tras la marcha de la Corte a Brasil, las tropas británicas, al mando del William Beresford, permanecieron sin demasiados obstáculos hasta 1820 en Portugal, que se convirtió de facto en un protectorado británico y en una colonia de Brasil, hasta el regreso del rey.

El levantamiento de Riego, en enero de 1820, animó a los patriotas liberales portugueses a rebelarse contra la ocupación británica. La revolución que estalló en Oporto el 24 de agosto de 1820 era tan nacionalista como liberal, al igual que la española de 1808. Expresaba el malestar de la mayoría de la población por la presencia británica, por la perdida del monopolio del mercado brasileño, desastrosa para la economía y la Hacienda portuguesas, así como por la ausencia del rey y de su familia, cuyo regreso inmediato exigieron. En 1820 se formó una Junta Provisória do Governo, que sustituyó a la Regencia y que en diciembre de ese año convocó 
elecciones a Cortes Constituyentes, que se celebraron conforme a las normas electorales contenidas en la Constitución de Cádiz. Las Cortes se reunieron en enero de 1821, bajo la presidencia de Manuel Fernándes Tomás, uno de los protagonistas de la revolución de 1820 y el más destacado miembro del "Sinedrio", la tertulia intelectual que la había alentado en Oporto y de la que formaban parte algunos relevantes comerciantes y varios oficiales del ejército.

\subsubsection{Las Cortes de 1821-1822}

Si la extracción profesional de estas Cortes (en la que abundaban sacerdotes, abogados, profesores de Universidad, propietarios rurales y comerciantes) era muy parecida a las de Cádiz, su filiación doctrinal recuerda también a las españolas, pero con algunas diferencias significativas, fruto en gran parte de los diez años que separaban a una y a otra. Había un grupo realista, escudado en la escolástica y partidario de reformar el armazón institucional de la monarquía tradicional, pero sin destruirlo. Un segundo grupo, en el que se mezclaban los argumentos escolásticos con los razonamientos tomados del pensamiento revolucionario francés, lo componían los sesenta y cuatro diputados de Brasil, aunque este grupo no llegase a tener el mismo peso específico que el que habían tenido los diputados americanos en las primeras Cortes españolas, entre otras cosas por su tardía incorporación a los debates constituyentes, después de que las Cortes aprobasen las Bases de la Constitución, de las que luego se hablará. Un tercer grupo lo formaban los diputados liberales de la metrópoli, en quienes recayó el protagonismo de estas Cortes y cuya filiación doctrinal era muy similar a la de los liberales de las Cortes de Cádiz y, más todavía, a la de los "exaltados" del Trienio. Dos de sus más destacados representantes eran Borges Carneiro y el mencionado Fernandes Tomás. Junto al iusnaturalismo racionalista (Locke, Rousseau, Sieyes), se percibe en ellos, en efecto, la influencia del historicismo nacionalista. Este componente doctrinal, además de aflorar en los debates constituyentes, se recogió en la propia Constitución de 1822, cuyo preámbulo, como el de la española de 1812, además de comenzar con una invocación a la Santísima e indivisivel trinidade, entroncaba el nuevo texto con las antiguas leis fundamentais da monarquía. Entre los liberales portugueses se detectaba, asimismo, el influjo del utilitarismo de Bentham, que en Cádiz, como queda dicho, había sido muy escaso, aunque no en las Cortes del Trienio, en donde el influjo del publicista inglés fue muy grande tanto entre los "exaltados" como entre los "moderados". Por otro 
lado, a diferencia de lo que había ocurrido en las Cortes de Cádiz, en las primeras Constituyentes portuguesas se aprecia también, como en las Cortes españolas del Trienio, la presencia de unos liberales moderados y anglófilos, que formaban una cuarta tendencia constitucional, minoritaria entonces, pero cuyas ideas se plasmarían cuatro después en la Carta de 1826. Su más destacado representante era el Duque de Palmela, cuyas tesis no eran muy distintas de las que ya por esa época sostenían en España Martínez de la Rosa o el Conde de Toreno.

El debate constitucional comenzó en enero de 1821. El 9 de Marzo de 1821 las Cortes aprobaron un decreto en el que se establecían las Bases da Constituição Portuguesa, que sirvieron de orientación para elaborar el texto constitucional articulado. Al presentarlas ante las Cortes, el presidente de la comisión constitucional que las había elaborado subrayó, como en España había hecho Argüelles en una ocasión similar, que los miembros de esa comisión no habían querido perderse "en el laberinto de las teorías de los publicistas modernos", sino que habían querido ir a buscar las bases de la nueva Constitución "en nuestro antiguo Derecho Público", en desuso por culpa de los "ministros despóticos", que adulaban a los reyes "a costa de los pueblos". El historicismo nacionalista era, pues, un venero doctrinal tan importante en el liberalismo "vintista" - siempre presto a recordar las Cortes de Lamego para justificar las innovaciones - como en el "doceañista", y que distinguía a ambos de la actitud antihistoricista que habían mantenido los "patriotas" franceses en la Asamblea de 1789 y muy señaladamente Sieyes. Las Bases se componían de treinta y siete principios, agrupados en dos secciones: una sobre los "Derechos Individuales de los Ciudadanos" y otra sobre "La Nación portuguesa, su Religión, Gobierno y Dinastía". Estas Bases fueron juradas por Juan VI el 3 de Julio, al poco de llegar a Lisboa, después de una ausencia de catorce años, y de acuerdo con ellas el 25 de Junio se presentó en las Cortes el proyecto de Constitución, compuesto de 240 artículos (ciento cuarenta menos que la de Cádiz), que después de un largo debate, se aprobó el 23 de septiembre de 1822, siendo jurada (que no sancionada) por el Rey Juan VI siete días más tarde. 


\subsubsection{La Constitución de 1822}

La primera Constitución portuguesa estaba marcadamente influida por la española de $1812 \mathrm{y}$, por tanto, indirectamente, por la francesa de 1791. Muchos de los preceptos del código portugués reproducían de manera casi literal el texto doceañista. Sin embargo, se observan algunas importantes diferencias. La primera de ellas se ponía de relieve en el primer título, "Dos direitos e deveres individuais dos portugueses", en el que se apreciaba el influjo de las declaraciones francesas de 1789 y 1795. A lo largo de diecinueve artículos se reconocían de forma ordenada un conjunto de derechos y deberes, la mayor parte de ellos recogidos también en la Constitución de Cádiz, aunque aquí, como se ha apuntado, de forma dispersa. Siguiendo los consejos de Bentham, las libertades de imprenta y de expresión se proclamaban en el código portugués de forma más amplia que en el de Cádiz, además de establecerse en sus artículos séptimo y octavo unas garantías jurisdiccionales inexistentes en el texto español. Pero, además, mientras el artículo 12 de esta Constitución había proclamado la intolerancia religiosa, el artículo 25 de la portuguesa, aun partiendo de la confesionalidad católica del Estado, admitía la libertad de cultos para los extranjeros: "A religião da Nação Portuguesa e a Católica, Apostólica, Romana. Permite-se contudo aos estrangeiros o exercício particular de seus respectivos cultos".

Como en la Constitución de Cádiz y en la francesa de 1791, el código "vintista" descansaba en dos grandes principios: el de soberanía nacional y el de división de poderes, que se recogían de forma expresa en los artículos 26 y 30, respectivamente. En virtud del primero, los constituyentes portugueses, al igual que habían hecho antes los españoles y los franceses, establecieron en el artículo 28 un procedimiento especial de reforma, que negaba al rey la sanción de las leyes constitucionales, y que incluía, contra el criterio expreso de Benhtam, una cláusula de intangibilidad temporal, similar a la que había establecido la Constitución de Cádiz, a tenor de la cual se impedía reformar la Constitución hasta que no hubiesen transcurrido cuatro años desde su publicación (en la de Cádiz eran ocho años hasta después de hallarse puesta en práctica en todas sus partes, según disponía su artículo 375).

En virtud del principio de división de poderes, el legislativo residía en "as Cortes com dependência da sanção do rei", y no "en las Cortes con el Rey”, como había establecido la Constitución de Cádiz; el judicial en los jueces y el ejecutivo en el rey y los secretarios de Estado, que lo ejercían bajo la autoridad del primero, una 
fórmula que difería de la empleada en Cádiz, que había atribuido el ejecutivo al rey en exclusiva. Al denominar los tres poderes básicos del Estado, la Constitución de 1822 mixturaba un criterio funcional, utilizado por la Constitución francesa del 91, con otro orgánico, seguido por la española del 12. Así hablaba "Do Poder Legislativo ou das Cortes", "Do Poder Executivo ou do Rei"y "Do Poder judicial".

Como en Cádiz, se establecía la incompatibilidad, tan criticada por Bentham, entre la condición de Diputado y el cargo de secretario de Estado o de cualquier empleo regio (art. 99), lo que no favorecía ciertamente el desarrollo parlamentario del sistema de gobierno, cuyos principios eran tan ajenos a este texto como lo habían sido al español del doce y al francés del 91. La responsabilidad de los ministros ante las Cortes se regulaba en términos exclusivamente penales (art. 10,3, 131, 159 y 160) y se desconocía la existencia del Gobierno como órgano colegiado.

En realidad, la Constitución portuguesa, como antes la de Cádiz y la francesa de 1791, articulaba un sistema asambleario de gobierno, con un monarca hereditario como Jefe del Estado. Si en Cádiz se había denominado "moderada" a esta monarquía, en Portugal prefería llamarse "constitucional hereditaria" (art. 29). En cualquier caso, en ambos textos se reducía de forma muy considerable los poderes regios, en beneficio de unas Cortes unicamerales, a quien se atribuía de forma primordial la dirección política del Estado. Conviene repetir que este radicalismo a la hora de regular los poderes del rey sólo se comprende cabalmente si se tiene en cuenta que en Portugal el rey estuvo ausente de su país desde 1807 a 1821, como había ocurrido en España desde 1808 a 1814, pues la presencia de ambos, sobre todo de Fernando VII, más obstinado y menos inteligente que Juan VI, hubiese dificultado sobremanera este vaciamiento del poder regio.

Por otro lado, la Constitución de 1822, como antes había hecho la de Cádiz, reconocía la capacidad electoral para elegir Diputados a la mayor parte de los varones mayores de edad que supiesen leer y escribir (art. 33), aunque para ser elegido requería una determinada renta, procedente de la tierra, la industria, el comercio o el ejercicio profesional (art. 34). El sufragio, por otro lado, pese a lo que había aconsejado el influyente Bentham, seguía siendo indirecto (arts. 44, 61 y 63), como en la Constitución de Cádiz. En cambio, la Constitución portuguesa se distanciaba de la española al permitir la reelección de los diputados (arts. 36), que también había defendido vivamente el publicista inglés. 
Las facultades de las Cortes y del rey eran casi idénticas a las de Cádiz y muy similar era también la regulación de la Regencia, de la diputación permanente de las Cortes y del Consejo de Estado, aunque en este caso su composición era distinta. Otras diferencias residían en el modo de regular la iniciativa legislativa, que la Constitución de 1822 atribuía a los ministros (art. 105), y no al Rey, como la de Cádiz, mientras que el veto que podía interponer el monarca a las leyes aprobadas por las Cortes sólo podía ejercerse una vez (art. 112) y no dos, como en Cádiz. En pocas palabras, las limitaciones del poder regio eran más acusadas en el texto "vintista" que en el "doceañista".

Otra rasgo muy peculiar de la Constitución portuguesa de 1822 era la forma de regular las relaciones entre Portugal y Brasil. Un asunto clave, del que dependía la propia estabilidad del Estado constitucional. Por ley de 16 de Diciembre de 1815, Juan VI había convertido al Brasil en reino, declarándolo unido a la antigua metrópoli, con lo que el antiguo reino de Portugal y Algarves se transformaba en el Reino Unido de Portugal, Brasil y Algarves. La Constitución de 1822, por su parte, definía la nación portuguesa "como la reunión de los portugueses de ambos hemisferios" (art. 20), siguiendo lo establecido en la de Cádiz, pero separándose de ésta, que no había previsto nada igual para las colonias ultramarinas, establecía un "Reino Unido" de Portugal y Brasil. Se trataba de una unión real entre ambos países, que llevaba consigo la creación de una delegación del poder ejecutivo en Brasil, que se encargaba a una Regencia compuesta por cinco personas (art. 128), una igual representación en las Cortes, a partir de la elección de un diputado por cada treinta mil habitantes (art. 37), una composición paritaria en el Consejo de Estado (art. 162) y un Tribunal Supremo de Justicia distinto al de la metrópoli (art. 193).

Estas concesiones no colmaron las expectativas de los diputados brasileños, que exigieron que el texto constitucional estableciese una asamblea parlamentaria para Brasil, sin perjuicio de que las Cortes debatiesen los asuntos comunes a los dos reinos. Una exigencia que fue rechazada por los diputados de la metrópoli. Este rechazo aceleró el proceso independentista, alentado por hombres como José Bonifácio de Andrada e Silva. En realidad, el sentimiento separatista se había fortalecido desde la instalación de la Corte en Rio de Janeiro, que había acarreado el fin del monopolio del comercio con Lisboa y, por tanto, la ruptura económica con la antigua metrópoli y la ligazón con la Gran Bretaña y los Estados Unidos de América, además de propiciar algunos enfrentamientos entre la elite gobernante de origen portugués y los nacidos en Bra- 
sil. En el auge del independentismo brasileño pesaba también el ejemplo de las colonias españolas e incluso el más lejano de los propios Estados Unidos. Pero no cabe duda de que la torpeza que demostraron los diputados metropolitanos al tratar la cuestión brasileña en las Constituyentes aceleró la independencia, que se proclamó formalmente el 7 de septiembre de 1822, apenas dos semanas antes de que se aprobase la primera Constitución portuguesa. Don Pedro, hijo primogénito de Juan VI, que se había negado a regresar a Lisboa, como le exigieron las Cortes, fue proclamado Emperador del Brasil.

La independencia de Brasil fue un mazazo para el flamante Estado constitucional portugués, pues el arreglo del problema colonial había sido uno de los objetivos primordiales de la revolución "vintista", junto al regreso del rey y a la vertebración de un nuevo Estado que garantizase la libertad y la independencia nacional. Pero aparte de ese importante fracaso, el liberalismo "vintista", apoyado socialmente sobre todo por los sectores más avanzados de la burguesía mercantil y profesional, debido a su radicalismo, concitó la inquina de la Corona y de la mayoría de la nobleza y al clero, que veían peligrar sus ancestrales privilegios con el nuevo orden constitucional, e incluso de la mayoría del pueblo, campesina y analfabeta, bajo la tutela ideológica de la Iglesia y cuyas condiciones de vida no habían mejorado desde la revolución de 1820.

\subsection{4 ¿Absolutismo o monarquía constitucional?}

El restablecimiento del absolutismo en España con la ayuda de la Santa Alianza alentó a las fuerzas hostiles al liberalismo "vintista" a derogar la Constitución de 1822, pero en este caso sin el apoyo de la Santa Alianza, vetado expresamente por la Gran Bretaña, por considerar que Portugal formaba parte de su zona de influencia. El 27 de mayo de 1823 se produjo un golpe de Estado, la "Vila-Francada", impulsado por algunas facciones del ejército, que contó con el activo respaldo de la reina Carlota Joaquina, hermana de Fernando VII, y de su hijo el infante Don Miguel. Al mes siguiente, Juan VI disolvió las Cortes Constituyentes, derogó la Constitución de 1822, declaró en pleno vigor las leyes tradicionales y mandó convocar las antiguas Cortes por estamentos. Su intención no era restablecer el absolutismo, como deseaban la reina y don Miguel, sino apadrinar una monarquía constitucional no muy distinta a la que había puesto en planta Luis XVIII en la Francia de 1814. Por otro lado, el rey evitó seguir la política represora contra 
los liberales que había llevado a cabo el vengativo Fernando VII en España. El 19 de junio, Juan VI nombró una comisión de catorce miembros, presidida por Palmela, encargada de elaborar un nuevo texto constitucional más acorde que la Constitución de 1822 con las leyes fundamentales o Constitución histórica de Portugal. Así nació un proyecto constitucional, elaborado sobre todo por Ricardo Raimundo Nogueira, que no llegó a entrar en vigor, por oposición de la Santa Alianza, aunque algunas de sus piezas básicas, como el reforzamiento del poder regio y el bicameralismo, pasarían a la Carta de 1826. Otro proyecto alternativo, pero circunscrito a la organización de las Cortes, fue el de Manuel Trigoso de Aragao Morato. Eran momentos de discrepancias entre los defensores más conciliadores del Antiguo Régimen, aliados a los liberales más moderados, partidarios de una monarquía constitucional conservadora, y los más intransigentes y cerriles, que apostaban fuerte por una solución absolutista. El 30 de Abril de 1824 (la llamada "Abrilada"), don Miguel, el exponente más destacado de estos últimos, dio a conocer una proclamación a favor de la restauración del absolutismo. Don Miguel fue detenido y enviado al exilio, en Viena, en donde permanecería hasta 1828 (mal sitio, desde luego, para un reciclaje liberal). Pero la solución constitucional no triunfó de momento. Lo que se mantuvo durante casi dos años fue una monarquía absoluta sin los tintes represivos de su homóloga española.

\section{3 "Cartismo" y "Moderantismo" - la Carta de 1826 y el Estatuto Real de 1834}

\subsection{El "cartismo" y la Carta de 1826}

Tras morir Juan VI, en marzo de 1826, su hijo, don Pedro I, emperador de Brasil, fue proclamado rey de Portugal con el nombre de Pedro IV. El 29 de abril de ese mismo año decidió aprobar una Carta constitucional muy similar a la que dos años antes había otorgado para Brasil. Al día siguiente de otorgarla, don Pedro convocó elecciones y el 2 de mayo abdicó a favor de su hija Maria da Glória, entonces una niña de siete años, pero con dos condiciones, luego incumplidas: que su hermano don Miguel, al que nombraba príncipe regente hasta que su hija fuese mayor de edad, contrajese matrimonio con ella más adelante y que respetase la Carta constitucional recién aprobada. 
La Carta de 1826, como la brasileña de 1824, se había inspirado en la francesa de 1814. Como ésta, respondía al principio monárquico, que se recogía en el preámbulo, sin duda de un tenor muy distinto al de la Constitución de 1822, pues en él don Pedro, rey de Portugal y de los Algarves, por la gracia de Dios (aunque desaparecían las referencias a la Santísima Trinidad), hacía saber a todos sus "súbditos portugueses" que era "Servido Decretar Dar e Mandar jurar inmediatamente pelas Tres Ordens do Estado a Carta Constitucional abaixo transcrita". La Carta de 1826, a diferencia de la francesa de 1814, regulaba un procedimiento de reforma constitucional distinto del legislativo ordinario, aunque este procedimiento especial, más complejo, no tenía que ser observado para la reforma de todos los preceptos de la Carta, sino tan sólo para aquellos que el artículo 144 - siguiendo a Benjamín Constant, la principal fuente doctrinal de la Carta - delimitaba como materia "constitucional": la relativa a los "límites y atribuciones respectivas de los poderes públicos y a los derechos políticos e individuales de los ciudadanos".

A diferencia de la Constitución de 1822, la Carta de 1826 no reconocía los derechos de los portugueses en su primer Título, sino en el último, junto a otras "disposiciones generales". En realidad, los derechos se reconocían en un solo y extenso artículo, el 145, que a lo largo de sus 34 parágrafos no hacía referencia alguna a los "deberes", como había hecho el texto "vintista", aunque sí a los derechos individuales basados en la tríada lockeana de libertad, seguridad y propiedad, definidos ahora de forma más concisa y sobria. La Carta de 1826 garantizaba, además, los “socorros públicos” (art. 145, 29), y una instrucción primaria gratuita (art. 145, 30), configurando, así, un interesante precedente de lo que a partir de 1848 se conocería en Europa como derechos sociales y que, en realidad, en buena medida no hacían más que recoger lo que la Constitución de 1822 había establecido en el capítulo cuarto de su título sexto (al margen, pues, del Título primero dedicado a regular los derechos de los portugueses), sobre los establecimientos públicos de instrucción pública y de caridad.

En lo que concierne a la organización de los poderes, las diferencias entre la Carta de 1826 y la Constitución de 1822 eran muy notables. El punto de partida ya no era sólo la "división" de poderes, como en el código "vintista", sino también la "armonía", como establecía el artículo 10 de la Carta. Las Cortes se dividían ahora en dos Cámaras: la de los Pares y la de los Diputados. La primera, vitalicia y hereditaria (art. 39); la segunda, elegida por un sufragio indirecto y censitario, tanto activo como pasivo, que reducían con- 
siderablemente el número de electores y más todavía el de elegidos (arts. 63 a 68), en relación a lo que había dispuesto la Constitución de 1822, de modo que las Cortes quedaban en manos de la nobleza terrateniente y de la burguesía industrial y financiera, de cuya fusión saldrían en adelante la clase sobre la que reposaría a lo largo del XIX la monarquía constitucional portuguesa, más especulativa y parasitaria que emprendedora y empresarial: los "barões", como los denominaría Almeida Garret en Viagens na Minha Terra, en donde los describe con el mismo desprecio del que luego harían gala Alexandro Herculano y Antero de Quental.

Por otra parte, el artículo 11 añadía a los tres clásicos poderes del Estado, el legislativo, el ejecutivo y el judicial, un cuarto poder: el "moderador" (art. 11), que el artículo 71 - siguiendo literalmente a Benjamín Constant - definía como "a chave de toda a organização política". Este poder "moderador" se atribuía al monarca, al que se concedía un conjunto de facultades que el código de 1822 no le había otorgado, como la de convocar, prorrogar y suspender las Cortes, así como la de disolver la Cámara de los Diputados, debiendo convocar elecciones generales inmediatamente. El monarca nombraba Pares sin número fijo, sancionaba las leyes, incluidas las constitucionales, nombraba y separaba libremente a los ministros y ejercía el derecho de gracia e indulto (art. 74). Se trataba de las competencias que Benjamín Constant había atribuido al Rey como pouvoir neutre.

La Carta de 1826, no obstante, se separaba del criterio del publicista suizo al no distinguir con claridad entre el poder regio y el ministerial. Según el artículo 75, en efecto, el rey, además de Jefe del Estado, era también el titular del poder ejecutivo - y como tal se le otorgaban amplias competencias en este campo -, aunque dicho artículo declarase que este poder lo debía ejercer a través de los ministros. El ministerio se regulaba en el mismo Título dedicado al rey (el quinto), si bien en un capítulo propio (el séptimo), con lo que la timidez a la hora de distinguir el poder regio del ministerial se confirmaba. La Carta, no obstante, permitía que el ministerio se articulase como un órgano colectivo y responsable políticamente ante el Parlamento, al permitir que los ministros pudiesen ser miembros de las Cámaras del Parlamento (arts. 28 y 42), aunque la responsabilidad ministerial se regulaba en términos puramente penales en el artículo 103. Por su parte, el artículo 72 declaraba inviolable y sagrada la persona del rey, mientras el 102 señalaba que todos los actos del poder ejecutivo serían inválidos sin el refrendo ministerial. 
En pocas palabras: la Carta de 1826, que entró en vigor a fines de julio de 1826, articulaba una monarquía constitucional próxima a la Carta francesa de 1814 e incluso más todavía al Acta Adicional de 1815. Un texto que Constant había redactado a petición de Napoleón para justificar constitucionalmente su "Imperio de los Cien Días". Como en toda monarquía constitucional, el desarrollo del sistema parlamentario dependía de las relaciones que en la práctica mantuviesen el monarca, el Gobierno y el Parlamento.

La potencialidad parlamentaria de la monarquía comenzó a desplegarse el mismo año de su aprobación. En octubre de 1826 comenzaron las sesiones de las Cortes, después de que Don Pedro nombrase a los Pares y de que se celebrase las elecciones a diputados. Antes de que acabase el año una moción de desconfianza contra un ministro provocó una crisis del Gabinete. Pero durante la primera vigencia de este texto se produjeron diversos enfrentamientos entre las dos Cámaras que componían las Cortes, que la Regencia en manos de la infanta doña Isabel María por deseo expreso de don Pedro - fue incapaz de moderar y que ponían de manifiesto las tensiones entre las fuerzas que apoyaban el Antiguo Régimen y las que defendían el Estado liberal.

En febrero de 1828 don Miguel regresó de su exilio vienés. Poco después disolvió la Cámara de los Diputados y convocó los tres estamentos del reino con el objeto de restablecer la vigencia de las leyes fundamentales de la monarquía tradicional, lo que obligó a don Pedro a anular el contrato de matrimonio de su hija doña Maria da Glória. Las Cortes, reunidas a la antigua usanza, proclamaron rey de Portugal a don Miguel y derogaron todas las medidas adoptadas por don Pedro, incluida la abdicación condicionada de sus derechos en su hija y la concesión de la Carta de 1826. Así comenzó un nuevo período absolutista en Portugal, que provocó una guerra civil entre los liberales (partidarios de María II) y los absolutistas (partidarios de don Miguel), que concluyó en mayo de 1834 con la victoria de los primeros. Merece la pena subrayar, a este respecto, que mientras el "miguelismo" estuvo en el poder seis años, el carlismo español, que comenzó la primera guerra civil en 1833, no lograría nunca alcanzarlo más que una parte del territorio nacional durante la primera y la tercera guerra carlista, lo que explica en buena medida que, una vez derrotado, el primero no fuese tan problemático como el segundo para la construcción del Estado liberal a lo largo del siglo XIX. 


\subsection{El triunfo del absolutismo en la Península ibérica y el exilio liberal}

El triunfo de don Miguel, en 1828, vino acompañado de una cruel persecución de los liberales, muchos de los cuales se vieron obligados a exiliarse en la Gran Bretaña y en Francia, sobre todo después de la revolución de 1830. Al primer país se dirigieron, por citar dos ejemplos, el duque de Palmela y el gran escritor romántico Almeida Garret; al segundo, en cambio, prefirió acogerse, en 1831, Alexandro Herculano, el otro gran exponente del primer romanticismo portugués y autor de una influyente História de Portugal (1846-1853). Otros exiliados se refugiaron en Brasil y otros, en fin, en la isla de Terceira, en las Azores, que permaneció fiel a las fuerzas liberales. Allí estableció Palmela una Regencia en Junio de 1829. A esta isla se dirigió don Pedro en 1832, después de ceder la Corona de Brasil a su hijo de cinco años Don Pedro de Alcántara (que la conservaría hasta la proclamación de la República en 1889), reservándose el título de duque de Bragança y de regente de Portugal, que mantuvo hasta su muerte, en septiembre de 1834. Su abdicación y su regreso a Europa ponían de relieve su decidida voluntad de pelear por los derechos de su hija doña Maria. Fue en esa isla de Terceira, bastión del liberalismo portugués, donde José Xavier Mouzinho da Silveira, futuro ministro de Hacienda y de Justicia, comenzó a diseñar toda una batería de medidas legislativas, sobre las que había reflexionado durante su exilio en París, que se pondrían en práctica, aunque no por entero, tras el definitivo triunfo liberal. Con estas medidas, desamortizadoras y centralizadoras, el pragmático liberal portugués pretendía asestar un golpe mortal a los privilegios de la nobleza y del clero, transformando en profundidad la sociedad, la economía, la Administración, la Hacienda y la Justicia portuguesas. Por su ambición y por su finalidad modernizadora pueden parangonarse con las que había auspiciado el marqués de Pombal en el último tercio del siglo XVIII y con las que sustentarían en España hombres como Javier de Burgos, el conde de Toreno y Mendizábal.

Desde 1828 a 1834 algunos exiliados portugueses (entre los que podía distinguirse una derecha aristocratizante, encarnada por Palmela, un centro positivista y burgués, representado por Mouzinho da Silveira, y una izquierda más o menos fiel al vintismo, cuyos principales exponentes eran el general Saldanha y Passos Manuel) coincidieron en el exilio con los liberales españoles, que se habían visto obligados a abandonar su patria en 1823. Y esta común experiencia tuvo una gran influencia en la evolución del libe- 
ralismo en los dos países ibéricos. Con una importante diferencia: los liberales portugueses - al menos los más templados - tenían como norte a la Carta de 1826, cuyo desarrollo había truncado el miguelismo triunfante en la guerra civil, los liberales españoles, en cambio, no tenían otra referencia constitucional válida que la Constitución de Cádiz, de la que muchos ya se habían distanciado durante el Trienio y de la que se alejarían todavía más durante el exilio, no sólo los "moderados", sino también no pocos "exaltados".

Tanto en Londres como en París - en esta ciudad sobre todo a partir de 1830 - los liberales españoles y portugueses siguieron leyendo con avidez a Bentham, así como a los más sobresalientes tratadistas franceses de la Restauración y de la monarquía orleanista, como Constant y Thiers, los doctrinarios Guizot y RoyerCollard, el romántico Chateaubriand y los positivistas Comte y Saint-Simon. Autores todos ellos conocidos ya en la España del Trienio y que en Portugal habían servido de cimiento doctrinal a la Carta de 1826. Característica común de estas disímiles orientaciones doctrinales europeas era el rechazo hacia los viejos apotegmas racionalistas del iusnaturalismo revolucionario, como el dogma de la soberanía nacional y el principio, tan mecanicista, de la división de poderes, frutos ambos de una concepción de la política y del Estado tildada ahora despectivamente de "dieciochesca".

Pero los liberales españoles y portugueses no se limitaron a profundizar en el estudio de las nuevas teorías políticas y constitucionales vigentes en Europa, tan distintas de las que habían inspirado a las Constituciones de 1812 y 1822 - tachadas por los más importantes publicistas europeos de poco acordes con "el espíritu del siglo" - sino que tuvieron oportunidad de conocer in situ el funcionamiento del sistema parlamentario de gobierno, al que los códigos "doceañista" y "vintista”, como antes la Constitución francesa de 1791, habían cerrado el paso, pero no la Carta de 1826, inspirada en las doctrinas constitucionales que estaban vigentes en la Europa más avanzada.

Falta un estudio detallado, desde una perspectiva históricoconstitucional, de los contactos personales y de los intercambios doctrinales entre los liberales españoles y portugueses durante estos años de exilio, aunque sí sabemos que estos contactos existieron, sobre todo a partir del triunfo de don Miguel en 1828. Por otro lado, puede afirmarse que los liberales españoles más moderados, agrupados en torno al periódico Ocios de Españoles Emigrados, que se publicó en Londres desde 1824 a 1827, acogieron con mucho interés y expectación la aprobación de la Carta portuguesa de 
1826. Baste recordar que en el número seis de este periódico, correspondiente al mes de octubre de 1826, un anónimo comentarista, que muy bien pudiera ser Canga Argüelles, elogiaba el modo "nuevo, pero muy filosófico" con que la Carta constitucional portuguesa aprobada ese mismo año, a la que se dedicaban fervientes elogios, distribuía los poderes del Estado, al añadirse a los tres clásicos poderes un cuarto, el "moderador", en manos del monarca. Esta actitud contrasta con el disgusto y alerta que causó la aprobación de la Carta en Fernando VII y sus ministros, quienes trataron de impedir por todos los medios que se consolidase una monarquía constitucional en el país vecino, barajando incluso la posibilidad de declararle la guerra, que se descartó al ser bien conscientes de que eso supondría enfrentarse con la Gran Bretaña. Lo que si hizo el Gobierno fernandino fue dar asilo a los rebeldes "miguelistas" y apoyarles en sus incursiones en territorio portugués, lo que provocó situaciones de gran tensión.

Es preciso recordar también que durante estos años de exilio algunos liberales españoles propusieron como rey de España a don Pedro I, al que presentaban como defensor de las libertades constitucionales, justificando formalmente tal decisión por entender que habían decaído los derechos de Fernando VII y de sus descendientes al haber violado la Constitución de Cádiz en 1814 y en 1823. Al ser don Pedro hijo de la hermana mayor del rey español, la Infanta Carlota Joaquina, se consideraba, además, que su acceso al trono de España respetaba una cierta legitimidad dinástica. Entre los liberales españoles partidarios de ofrecer la Corona española a don Pedro y de crear, así, la ansiada "Unión Ibérica" bajo su trono, había "moderados", como Andrés Borrego, pero también algunos destacados "exaltados", como Álvaro Flórez Estrada, lo que permite deducir, por su trayectoria política anterior y posterior, que tal propuesta no significaba necesariamente aceptar los postulados políticos del "cartismo", pero sí, quizá, una actualización de la Constitución de 1812, de la que muchos liberales españoles, desde luego los "moderados", pero también no pocos "exaltados", dieron muestras durante esos años de exilio de haberse distanciado. En 1828 se creó en Londres un "Club Hispano-Lusitano", que agrupaba a exiliados de ambos países con el propósito de restaurar en ellos el Estado constitucional, mediante una monarquía a cuya cabeza figuraría don Pedro Las esperanzas puestas por los exiliados españoles en ese monarca se reforzaron con su llegada a Europa, en 1832, y se mantendrían hasta el fallecimiento de Fernando VII, en septiembre de 1833, que, como es sabido, dio lugar a una guerra civil entre los partidarios de doña Isabel, en quien los libe- 
rales españoles comenzaron a cifrar sus esperanzas, y los de su tío don Carlos. Una guerra que tan estrecha relación guardaba con la que estaba a punto de finalizar en Portugal entre los partidarios de don Miguel y los de doña María.

Julio de 1830 supuso un hito importante en la historia del liberalismo europeo y también en la de las dos naciones ibéricas. Merced a la revolución que ese mes estalló en París, Francia recuperó su prestigio entre los liberales europeos, inquietos por la deriva autoritaria que había tomado la monarquía borbónica desde el acceso al trono de Carlos X, en 1824. El impacto de la Revolución de Julio fue especialmente intenso en Bélgica, que en 1831 consiguió aprobar una Constitución que consolidaba su independencia de Holanda y que establecía un orden liberal progresista que ejercería notable influjo en la Europa del siglo XIX. Un año más tarde, la Gran Bretaña, la nación que siempre se había adelantado a la Europa continental y cuyo Gobierno presidía entonces el whig Lord Grey, sintonizaba por vez primera desde hacía dos siglos con los cambios habidos en "el continente" e incluso se sumaba a ellos al aprobar el 7 de junio de 1832 una ley, la Reform Act, que supuso un impulso muy considerable para el desarrollo del sistema parlamentario de gobierno.

A todos estos cambios no podían sustraerse ni España ni Portugal. La victoria de la monarquía constitucional sobre el absolutismo de don Miguel y de Fernando VI - o de don Carlos, cuando, a la muerte de Fernando VII, disputó el trono a su sobrina, la futura Isabel II - se debía a causas muy variadas, pero sin duda influyó de forma decisiva el nuevo contexto internacional que nació en Europa después la Revolución de Julio y que cristalizaría el 22 de abril de 1834 con la firma del Tratado de la Cuádruple Alianza, integrada por Inglaterra, Francia y las dos naciones ibéricas. Para contrarrestar el apoyo que Rusia, Prusia, Austria y el Vaticano prestaron a don Miguel y a don Carlos, la Gran Bretaña y Francia, las dos naciones más poderosas de la Europa occidental, unidas por vez primera en defensa del liberalismo, apoyaron sin reservas las pretensiones dinásticas de doña Maria y doña Isabel, cuyos tronos encarnaban un modelo de monarquía constitucional que, desde su nacimiento en la Inglaterra de 1688 y sobre todo a lo largo del siglo XVIII y durante el primer tercio del XIX, el liberalismo moderado continental había reivindicado, primero, frente a la monarquía absoluta y, después, frente a la monarquía asamblearia nacida de la Revolución francesa.

El apoyo de Inglaterra y Francia no explicaba por sí solo, desde luego, el triunfo de la monarquía constitucional en Portugal 
y España. En estas dos últimas naciones, como antes había ocurrido en las dos primeras, el triunfo de esta forma de monarquía era además fruto de un pacto entre los sectores menos absolutistas de la nobleza, del clero y de los altos cuerpos de la Administración y los más templados de la burguesía liberal. Si este pacto trajo consigo en Portugal el restablecimiento de la Carta de 1826, en mayo de 1834, bajo el Gobierno del duque de Palmela, en España supuso el respaldo al Estatuto Real, bajo el Gobierno de Martínez de la Rosa. Como ya se ha hablado de la Carta - cuya segunda vigencia, de 1834 a 1836, estuvo lastrada por el enfrentamiento entre los "cartistas" y los "demócratas", partidarios de la Constitución de 1822 conviene a continuación decir dos palabra, no más, sobre el Estatuto. (y repárese que en ambos casos se evitaba cuidadosamente el nombre de "Constitución", de connotaciones revolucionarias).

\subsection{El liberalismo "moderado" y el Estatuto Real de 1834}

En el Estatuto Real, sancionado por la Reina Gobernadora, María Cristina de Borbón, viuda de Fernando VII; el 10 de abril de 1834, se hacía patente la concepción del Estado constitucional que tenía el partido moderado, muy distinta de la que había inspirado a la Constitución de Cádiz. Todo atisbo iusracionalista se esfumaba. De ahí que el Estatuto no apelase a la soberanía de la nación ni a su poder constituyente. Su patente historicismo era, además, de muy distinta factura al que en las Cortes de Cádiz habían defendido los Diputados liberales, señaladamente Argüelles. Basta cotejar el discurso preliminar al código del doce con la Exposición del Consejo de Ministros a Su Majestad la Reina Gobernadora, que precede al Estatuto Real. La diferencia es notoria. El historicismo que inspiraba a los redactores de este último texto era de corte jovellanista, muy parecido al que los realistas habían defendido en Cádiz, además de poner de relieve el impacto de los doctrinarios franceses, de Guizot en particular, e indirectamente, a su través, el influjo del romanticismo conservador alemán. La historia, una supuesta historia identificada con una cierta tradición, actuaba como freno a la razón y, por tanto, a toda suerte de innovaciones tenidas por peligrosas, que se rechazaban por ajenas a la Constitución tradicional o histórica de España. De este modo, en el Estatuto Real se plasmaba el sustento filosófico básico del constitucionalismo moderado así como, implícitamente, una de sus más importantes premisas, sino la más: la doctrina de la "soberanía compartida" 
entre el rey y las Cortes, que se recogería de forma explícita en el preámbulo de la Constitución de 1845 y luego en la de 1876.

Pero el Estatuto Real también regulaba los poderes del Estado de una manera muy distinta a como lo había hecho la Constitución de Cádiz y no muy diferente a como se establecía en la Carta francesa de 1814 y en la portuguesa de 1826. Las atribuciones de la Corona se reforzaban con la concesión al monarca, entre otras muchas prerrogativas, del derecho de disolución del Parlamento y del veto absoluto de las leyes aprobadas por las Cortes. Éstas se componían de dos Cámaras: el Estamento de Procuradores y el Estamento de Próceres. Rancios nombres, gratos para el gusto de las generaciones adictas al liberalismo templado y doctrinario. Debe tenerse en cuenta, asimismo, que bajo la vigencia del Estatuto Real se cambió el sistema electoral gaditano, indirecto y amplio, por otro directo y que restringía de forma considerable el electorado activo y pasivo. Elegir y poder ser elegido miembro del Parlamento era ahora patrimonio exclusivo de la nobleza, de las altas jerarquías eclesiásticas y militares y de una minoría de burgueses.

Por otro lado, merced al Estatuto Real y a sus leyes complementarias se introdujo en España, por vez primera, el sistema de gobierno parlamentario El Consejo de Ministros y la presidencia del Gobierno se reconocían en el texto del Estatuto, mientras los reglamentos de las Cámaras recogieron la compatibilidad entre el cargo de ministro y la condición de diputado. Durante los dos años de vigencia del Estatuto - en el que sucedieron cuatro Gobiernos, presididos por Martínez de la Rosa, Toreno, Mendizábal e Istúriz - se fueron asentando mecanismos típicamente parlamentarios, como la contestación al discurso de la Corona, las "proposiciones", el examen de la ley de Presupuestos y de las "peticiones", las "preguntas", la "cuestión de Gabinete" y el "voto de censura".

Se trataba de un programa depurado, nada improvisado, sino fruto de la evolución que la tendencia más conservadora del liberalismo español, con el Conde de Toreno a la cabeza, había experimentado en los exilios y que, como se ha visto, algunos habían querido implantar durante el Trienio Constitucional. 


\section{4 "Progressismo" y "Setembrismo" - las constituciones de 1837 y 1838}

\subsection{El liberalismo progresista y la Constitución de 1837}

Los exilios y la experiencia del Trienio Constitucional habían modificado también las ideas de los progresistas, cuyos más destacados representantes eran Agustín Argüelles, José María Calatrava, Vicente Sancho y los jóvenes Joaquín María López y Salustiano de Olózaga, además de Juan Álvarez Mendizábal. El reforzamiento de los poderes de la Corona en relación a lo que había dispuesto la Constitución de Cádiz, la estructura bicameral de las Cortes, el sistema electoral directo y censitario, los mecanismos básicos del sistema parlamentario de gobierno, eran premisas que muchos progresistas aceptaban a la muerte de Fernando VII. Los dos años de Estatuto, al llevarlas a la práctica, fortalecieron los motivos de esta aceptación y la extendieron entre los miembros de esta tendencia liberal.

Desde luego, la aceptación de estas premisas era muy matizada. Deseaban, sí, ampliar los poderes de la Corona en relación a lo que disponía la Constitución de 1812, pero no tanto como el Estatuto sancionaba. Un texto que ni siquiera concedía la iniciativa legislativa a las Cámaras, reservándola en exclusiva al monarca o, en la práctica, al Gobierno. Querían, desde luego, que las Cortes se dividiesen en dos Cámaras, pero no les satisfacía el criterio que los moderados habían seguido, sobre todo al determinar la composición del Estamento de Próceres. Abogaban, en fin, por un sistema electoral menos generoso que el gaditano, pero no por uno tan cicatero como el que establecía el Estatuto, que excluía a buena parte de las clases medias, su principal clientela electoral. Existían, pues, diferencias a la hora de establecer y aplicar las premisas que se vienen señalando. Mas eran diferencias de grado y no de fondo.

Había, en cambio, dos aspectos del Estatuto Real que lo convertían, a juicio del progresismo, en un código inaceptable. Primero su mismo origen. El haber sido elaborado al margen de la voluntad nacional. Por este vicio radical, el Estatuto era tachado de simple Carta otorgada por la Corona. Pero además los progresistas consideraban inadmisible que el Estatuto careciese de una declaración de derechos. En virtud de estas dos tachas entendían que el Estatuto no era una verdadera Constitución, sino una simple e insuficiente Ley Orgánica. La lucha por el principio de soberanía nacional y por el reconocimiento constitucional de los derechos se convirtió, así, en el Leitmotiv del progresismo desde 1834 a 1836. 
Se comprende, pues, que durante estos dos años los progresistas exigiesen, en las Cortes y en la calle, el restablecimiento de la Constitución de Cádiz. A pesar de sus muchos defectos, seguía siendo el único código constitucional que hasta aquel momento la nación se había dado a sí misma y en la que se recogían, aunque no de forma ordenada, los derechos que tanto anhelaban, y entre ellos uno sobremanera importante: la libertad de imprenta. Ahora bien, el deseo de restablecer el código doceañista venía acompañado, por parte de la mayoría de los progresistas, de un franco deseo de reformarlo en profundidad. En realidad, puede decirse que al exigir su restablecimiento no se expresaba tanto un sentimiento positivo como negativo: no era un "sî́" a la Constitución de Cádiz, era más bien un "no" al Estatuto Real.

Y de hecho este restablecimiento fue efímero. Ocurrió como consecuencia de los movimientos revolucionarios que se desataron en toda España desde comienzos de julio de 1836, auspiciados por los progresistas, como había ocurrido con los del año anterior, y en los que se puso de relieve la doble intención de restaurar y revisar la Constitución de Cádiz. Este movimiento insurreccional concluyó el 13 de agosto, cuando la reina regente, presionada por un grupo de sargentos que habían conseguido acceder a su palacio veraniego de La Granja, se vio obligada a expedir un decreto en el que ordenaba publicar la Constitución de Cádiz, "en el ínterin que reunida la nación en Cortes manifieste expresamente su voluntad... o dé otra Constitución conforme a las necesidades de la misma". El 21 de agosto, nombrado ya el nuevo Gobierno Calatrava, del que formaba parte Mendizábal, se publicó otro decreto convocando elecciones, con el objeto de que "la nación reunida en Cortes manifieste expresamente su voluntad acerca de la Constitución que ha de regirla o de otra conforme a sus necesidades". Las elecciones se celebraron durante los meses de septiembre y octubre y los progresistas obtuvieron una amplia victoria. El 24 de este último mes, las Cortes, compuestas de una sola Cámara, y en las que era patente el influjo de Bentham y de Constant, inauguraron sus sesiones, y el 18 de junio de 1837 aprobaron una nueva Constitución, más avanzada que el Estatuto Real, pero menos que la de 1812, en la que se establecía la organización del Estado constitucional que estaría vigente hasta la dictadura de Primo de Rivera.

El código de 1837 era, en realidad, una Constitución transaccional, fruto de un pacto político entre los dos grandes partidos liberales, el progresista y el moderado. Un pacto alentado por la guerra carlista y por las presiones que ejercieron sobre el Gobierno Calatrava Francia e Inglaterra. Pero además de a un pacto político 
de carácter coyuntural, el carácter transaccional de la Constitución de 1837 se debía también a la confluencia doctrinal que se apreciaba en el seno de los dos grandes partidos liberales españoles tras las amargas experiencias del Trienio y del exilio.

El carácter transaccional de este código se manifiesta en tres aspectos diferentes. En primer lugar, en la amalgama de principios, unos progresistas y otros moderados, que en ella se recogían. Era una Constitución doctrinalmente simbiótica. Se estampaban en su articulado premisas de marcada impronta progresista, como el dogma de soberanía nacional, la libertad de imprenta sin previa censura, el instituto del Jurado y el de la Milicia Nacional, las amplias facultades de las Cortes en orden a la sucesión de la Corona, así como la índole electiva de Ayuntamientos y Diputaciones Provinciales. Pero al lado de estas premisas se insertaban otras consustanciales al ideario moderado, como la flexibilidad constitucional (esto es, la entonces llamada "omnipotencia del Parlamento", en virtud de la cual se excluía una cláusula especial de reforma constitucional, presente en el código doceañista), el bicameralismo, el sistema electoral directo y, sobre todo, el reforzamiento de los poderes de la Corona, en detrimento de la autonomía de las Cortes: su Diputación Permanente, en efecto, se suprimía y, en cambio, al rey se concedía la facultad de convocar y disolver el Parlamento, así como de suspender y cerrar sus sesiones y la de nombrar al presidente y vicepresidente del Senado. Pero, muy especialmente, al monarca se otorgaba la iniciativa legislativa y la sanción de las leyes, lo que llevaba aparejado la posibilidad de interponer su veto de forma absoluta y no, como había dispuesto la Constitución de Cádiz, de forma meramente suspensiva.

Pero en la Constitución de 1837 no se trató solamente de incorporar principios de ambas canteras doctrinales. Estos principios, además, se consignaron sensiblemente atenuados, en una deliberada búsqueda de conciliación doctrinal. Era por ello, además de simbiótica, una Constitución sincrética. Ahí se encuentra el segundo aspecto que confiere a este texto un inequívoco carácter transaccional. De este modo, aunque se recogía el dogma de la soberanía nacional, tal dogma se excluía del articulado para pasar a formar parte del preámbulo y, muy particularmente, sin que se consagrase una de sus más importantes consecuencias, a la que antes se hizo referencia: la creación de un órgano parlamentario especial, que, sin la intervención de la Corona, se ocupase de modificar el texto constitucional. Esta curiosa mixtura de soberanía nacional y flexibilidad, incoherente en el plano de los principios, confiere al código de 1837 una notable singularidad en nuestra historia consti- 
tucional. Por otro lado, la composición del Senado traslucía también el espíritu sincrético que animó a los constituyentes de 1837, al combinar el sistema electivo con la designación regia: se elegían tres senadores por provincia y, entre esta terna, el rey nombraba uno. Igualmente, la convocatoria regia de las Cortes no excluía la convocatoria automática de las mismas, sino que ambos principios, de dispar procedencia doctrinal, se consignaron a la vez en el texto de 1837. Por último, este ánimo dulcificador se manifiesta en lo tocante a las relaciones entre el Estado y la Iglesia. El artículo 11 de la Constitución no consagraba la libertad de cultos, pero tampoco la confesionalidad religiosa, que había establecido la Constitución de Cádiz y por la que se inclinaban no pocos hombres del partido moderado. Este vidrioso asunto se despachaba con una redacción huidiza y ambigua, no exenta de habilidad, que se limitaba a afirmar literalmente: "la nación se obliga a mantener el culto y los ministros de la religión católica que profesan los españoles".

Por último, el carácter transaccional del código de 1837 se reforzaba por un tercer aspecto, a saber: el abanico de posibilidades que esta Constitución permitía para que, sin salirse de lo constitucionalmente lícito, se diseñasen diversos órdenes políticos fundamentales. Esta Constitución, pues, sobre ser simbiótica y sincrética, era además elástica. Esta elasticidad era consecuencia de las numerosas remisiones al legislador ordinario, con la finalidad de que éste legislase a su sabor sobre aspectos capitales de la organización estatal. Así acontecía con materias tan importantes como la libertad de imprenta, la ley electoral, la organización del Jurado, de la Milicia Nacional, de los Ayuntamientos y Diputaciones, y del poder judicial. La Constitución sólo se ocupaba de reseñar las bases mínimas-muy mínimas- que habrían de presidir el ulterior desarrollo normativo.

Si el carácter simbiótico de esta Constitución obedecía sobre todo a una confluencia doctrinal entre el partido progresista y el moderado, que hundía sus raíces en los fracasos de 1814 y 1823, así como en los exilios subsiguientes, su carácter sincrético y elástico venía motivado fundamentalmente por un acuerdo político entre estos dos partidos, con el objeto, ya mencionado, de vencer al carlismo, atraer a la Europa liberal y, en definitiva, consolidar el nuevo Estado constitucional, sin olvidarse de las necesidad de amparar las expectativas abiertas por la vasta operación desamortizadora, impulsada por los mismos autores de la Constitución de 1837, muy singularmente por Mendizábal, de nuevo al frente de la cartera de Hacienda en el Gobierno Calatrava. Se trataba, en definitiva, de establecer una legalidad fundamental equidistante de la Consti- 
tución de 1812 y del Estatuto Real de 1834, una vía media entre estos dos códigos, carentes de suficiente fuerza integradora: el uno por demasiado avanzado, el otro por demasiado comedido.

\subsection{El liberalismo "setembrista" y la Constitución de 1838}

El 9 de septiembre de 1836 tuvo lugar en Lisboa un golpe de Estado muy parecido al que se había dado en La Granja un mes antes, cuyos protagonistas fueron algunos destacamentos de las Guardias Nacionales, que tenían como objetivo desplazar a los "cartistas" del poder y exigir que doña María II destituyese al duque de Palmela, derogase la Carta de 1826 y restableciese, al menos de forma provisional, la Constitución de 1822. El motín triunfó y con él nació el "setembrismo", un movimiento apoyado por las clases medias excluidas del sistema político establecido por la Carta (profesionales, comerciantes, funcionarios), pero que contaba también con un indudable respaldo entre algunos sectores populares de Lisboa y de otras ciudades. El "setembrismo" guarda un indudable paralelismo con el "progresismo" español de esos años, aunque, a diferencia de éste, más que un partido era un movimiento, cuyos más destacados dirigentes eran Rodrigo da Fonseca Magalhaes y sobre todo Passos Manuel.

Mediante el decreto de 10 de septiembre de 1836, el Gobierno salido de la Revolución, del que formaban parte el mencionado Passos Manuel, Sá da Bandeira y Vieira de Castro, declaraba nuevamente en vigor la Constitución de 1822, pero a la vez convocaba elecciones a Cortes Constituyentes, con el objeto de que éstas introdujesen en la Constitución de 1822 "las modificaciones que entendiesen convenientes". El paralelismo con el decreto arrancado a María Cristina en España el 13 de agosto era evidente. Mediante un nuevo decreto de 11 de octubre de 1836, el Gobierno, que no se sujetó nunca a la estricta legalidad del código "vintista" restaurado, había determinado que los diputados de las futuras Cortes constituyentes tuviesen poderes bastantes para "rever, derogar ou alterar quaisquer artigos" de la Constitución de 1822, así como para "acrescentar outros e fazer-lhe enfim as modificações que julgarem convenientes". Este decreto provocó una inmediata reacción de los "cartistas", quienes defendieron la validez de la Carta de 1826 y recordaron su valor como símbolo de la libertad durante el exilio y la guerra civil. Para integrar en la obra constituyente a esta poderosa corriente de opinión, el Gobierno aprobó un nuevo decreto el 6 de noviembre de 1836, en el que se redactaban de nue- 
vo los poderes de los futuros diputados, a los que ahora se autorizaba a hacer tanto en la Constitución de 1822 como en la Carta de 1826 "as alterações que julgarem necessárias, a fim de esabelecerem uma lei fundamental que assegure a liberdade legal da Nação, as prerrogativas do Trono constitucional e que esteja em harmonia com as monarquias constitucionais da Europa”. Una fórmula que ponía de relieve con toda claridad la voluntad conciliadora del nuevo Gobierno así como el alcance de las futuras Cortes Constituyentes, destinadas a elaborar un texto válido para los "vintistas" o "demócratas" como para los "cartistas" - Passos Manuel insistiría en que la Constitución no debía ser la bandera de un partido, sino que debía estar por encima de todos ellos- y que a la vez fuese aceptado por las naciones integrantes de la Cuádruple Alianza, sobre todo por la Gran Bretaña y Francia.

Y así lo hicieron los Diputados que se reunieron en enero de 1838 y que dos meses más tarde aprobaron una nueva Constitución, que suponía una vía media entre la de 1822 y la Carta de 1826, de la misma manera que lo había sido la española de 1837 - sin duda la referencia más importante - entre la Constitución de Cádiz y el Estatuto Real. Si la Constitución de 1822, como antes la de Cádiz y la francesa de 1791, había sido impuesta por las Cortes al monarca, y la de 1826, como el Estatuto Real y la Carta francesa de 1814, había sido otorgada por éste, la de de 1838, en los mismos términos que la española de 1837 y la francesa de 1830, si bien fue obra de unas Cortes Constituyentes, fue sometida a la aceptación de la Corona, por lo que podía considerarse que había sido fruto de un pacto entre ambas instituciones. Esta naturaleza paccionada se ponía de relieve en el preámbulo, en el que doña María hacía saber a su súbditos "que as Cortes Gerais, Extraordinarias, e Constituintes Decretaram, e Eu acetei, e Jurei “ la Constitución, que precisamente llevaba la fecha del día de la aceptación regia, el 3 de abril de 1838.

El principio de soberanía nacional, clave de los idearios "vintista" y "septembrista", se recogió en el texto de la Constitución y no sólo en su preámbulo, como había ocurrido en la Constitución española de 1837. Así, en efecto, el artículo 33 señalaba que "a soberanía reside essencialmente em a nação, da qual emanan todos os poderes políticos". En coherencia con este principio, la Constitución de 1838, a diferencia de la española de 1837, que había guardado deliberado silencio sobre este asunto, regulaba en su título XI un procedimiento especial de reforma constitucional, sencillo y claro, que afectaba a todos los preceptos y no sólo a aquellos considerados materialmente constitucionales, como había he- 
cho la Carta de 1826. Sin embargo, al igual que en la Carta y a diferencia de la Constitución de 1822, en este procedimiento de reforma participaban no sólo las Cortes- las dos Cámaras en las que éstas se dividían, aunque sólo el Congreso de los Diputados podía proponerla-sino también el monarca, que debía sancionar la reforma propuesta, aunque en caso de ser ratificada por las Cortes siguientes, la reforma constitucional se consideraría aprobada sin necesidad de sanción regia. En definitiva, se trataba de un procedimiento que recordaba en parte al establecido en la Constitución de 1822 y en parte también a la Carta de 1826.

Una mixtura similar se percibe en el Título III, "Dos Direitos e Garantías dos Portugueses", en donde se recogían los derechos recogidos en la Constitución de 1822 y en la Carta de 1826, incluidos la "instrucción primaria gratuita" y los "socorros públicos" (art. 28, I y III), que no figuraban ni en la Carta francesa de $1830 \mathrm{ni}$ en la española de 1837, pero sí el primero de ellos en la belga de 1831. La Constitución portuguesa de 1838 reconocía también los derechos de asociación y de reunión (art. 14), hasta entonces desconocidos en el constitucionalismo portugués y en el español. La mentalidad burguesa y utilitaria se ponía de relieve en la redacción de los artículos 20, que abolía "todos os privilégios que não forem essencialmente fundados em utilidade pública" y el 30, que se refería al "talento, mérito e virtudes" como únicos criterios para acceder a los cargos públicos. En lo que concierne a la libertad religiosa, el artículo 3 declaraba como "religión de Estado" la católica, apostólica y romana, pero el 11 señalaba que nadie podía ser perseguido por motivos de religión, "contanto que respeite a do Estado".

En lo atinente a la organización de los poderes del Estado, el artículo 34 de la Constitución de 1838 volvía al esquema tripartito de 1822 y, por tanto, no reconocía la existencia de un poder "moderador", como había hecho la Carta de 1826. El artículo 35, por su parte, insistía en que estos poderes eran "essencialmente independentes; nenhum pode arrogar as atribuiçoes do outro", sin que se mencionase ya la "armonía" entre ellos, como había hecho el texto de 1826. No obstante, la Constitución de 1838, como la Carta de 1826 y, en realidad, como todas las que entonces estaban en vigor en Europa, aceptaba la estructura bicameral de las Cortes, que los "vintistas" habían rechazado en 1822, siguiendo los pasos de la Constitución de Cádiz y de la francesa de 1791. Las Cortes ahora se dividían en dos Cámaras, "la Cámara de los Senadores" y la "Cámara de los Diputados" (art. 36). Pero mientras la Carta de 1826 había establecido una Cámara de los Pares hereditaria, los consti- 
tuyentes de 1838 se inclinaban ahora por una Cámara Alta "electiva e temporária" (art. 58), aunque un artículo transitorio al final del texto dejaba a la libre decisión de las Cortes ordinarias siguientes si los Senadores serían elegido por el cuerpo electoral o designados por la Corona a partir de una lista triple propuesta por los electores (fórmula esta última que era la que seguía la Constitución española de 1837), pero siempre dentro de un reducido círculo de propietarios, comerciantes, fabricantes, y altos cargos de la Iglesia y del Estado (art. 77). La Cámara de los Diputados se elegía por un sufragio directo (art. 71) - una diferencia importante con la Carta de 1826 - pero también censitario (art. 74), que reducía el número de los electores y de los elegidos en relación a lo dispuesto en la Constitución de 1822 (arts. 72 a 74).

El artículo 80 definía al monarca como "Chefe do Poder Ejecutivo", aunque añadía que dicho poder se ejercía a través de los "ministros y de los Secretarios de Estado". Tanto unos como otros podían ser diputado o senadores (arts. 50 y 65), a diferencia de lo que había establecido la Constitución de 1822. Al monarca se conferían atribuciones muy relevantes, ya reconocidas en la Carta de 1826, como la sanción de las leyes, lo que implicaba la posibilidad de un veto absoluto y no meramente suspensivo, como el que había establecido la Constitución de 1822, la disolución de la Cámara de Diputados, así como el nombramiento y la destitución de los ministros (arts. 81 y 82), aunque los artículos 83 y 84 introducían la fórmula " o Rei não pode", y "O Rei não pode sem consentimento das Cortes", que recordaban a la Constitución de 1822 y en virtud de la cual se prohibía al monarca "ser al mismo tiempo Jefe de otro Estado", así como ausentarse de Portugal sin consentimiento de las Cortes. La Constitución de 1838 reducía, asimismo, las amplias facultades que la Carta había otorgado al monarca en el ámbito de las relaciones internacionales, muy en particular al otorgar a las Cortes, y no al monarca, como había hecho la Carta (art. 75, 8º), la facultad de aprobar los tratados de naturaleza militar y comercial, antes de ser ratificados por el monarca (art. 36, IX y 81, XV). Un cambio muy importante para los septembristas, partidarios de una política económica proteccionista, a diferencia de librecambismo sustentado por los cartistas, sin duda favorable a los intereses británicos. La Constitución de 1838 restringía también los poderes que la Carta había dado al rey en el ámbito de la función jurisidiccional, como el derecho de indulto, que ahora debía ejercerse de conformidad con las leyes (art. 81, X).

Esta Constitución, en fin, disponía que los ayuntamientos (Cámaras municipais) serían elegidos directamente por el pueblo 
(art. 130), cosa que la Carta de 1826 no había garantizado en su artículo 134, en el que se remitía a una legislación posterior para regular la elección de los concejales (Vereadores).

\section{El restablecimiento de la Carta de 1826 y la aprobación de la Constitución de 1845}

La vigencia de la Constitución de 1838 se interrumpió definitivamente el 27 de enero de 1842, a raíz del golpe militar promovido en Oporto, con el consentimiento del Palacio, por Antonio Bernardo da Costa Cabral, un antiguo revolucionario que se había vuelto conservador, a quien Oliveira Martins denominaría "o novo marqués de Pombal do constitucionalismo". Mediante un decreto de 19 de febrero, Cabral restauró la vigencia de la Carta de 1826 era la tercera y definitiva - y se aseguró más tarde una holgada y disciplinada mayoría en las Cortes, que le permitió gobernar de forma muy autoritaria los años siguientes, sofocando el levantamiento "septembrista" de 1844, aunque la revuelta campesina de "María da Fonte", en 1846, le obligó a ceder el poder al duque de Saldaña, quien tuvo que enfrentarse en 1847 al conflicto de "A Patuleia", una sublevación civil y militar de carácter democrático y urbano, que provocó una breve guerra civil, que finalizó gracias a la intervención militar inglesa y española. En 1849 Costa Cabral sucedió a Saldanha en el Gobierno, a cuyo frente se mantendría hasta 1851, cuando fue sustituido de nuevo por Saldanha, dando lugar a la llamada "Regeneração", que, bajo la vigencia de la Carta de 1826, daría a Portugal una estabilidad constitucional notable, desde luego mayor que la que había tenido durante la primera mitad del siglo y superior también a la que tendría España, aunque la Carta fue objeto de cuatro reformas, en 1852, en 1885, en 18951896 y en 1907, destinadas a democratizar la monarquía, hasta su derogación definitiva el 10 de octubre de 1910, fecha en que se proclamó la I República portuguesa.

En lo que concierne a España, los "moderados" González Bravo y Narvaez retomaron en 1844 el poder, que durante el trienio esparterista había estado en manos de los progresistas. Las Cortes comenzaron ese mismo año a reformar la Constitución de 1837 y a aprobar el año siguiente una nueva Constitución, en donde de establecieron, con muchas mayor claridad que en el Estatuto Real, los principios básicos del constitucionalismo moderado, con exclusión de los progresistas, lo que suponía romper de forma unilateral el acuerdo constitucional de 1837, aunque la estructura 
básica de la monarquía constitucional se mantuvo. Muy en particular en el texto de 1845 se plasmaban la doctrina de la soberanía compartida entre el rey y las Cortes y la concepción jovellanista de una constitución histórica de España, no necesariamente escrita, anterior y superior al texto constitucional. Dos ideas básicas que en las Cortes de 1844-1845 defendieron, entre otros, Donoso Cortés y Pedro José Pidal. Pero la monarquía constitucional que puso en planta la Constitución de 1845 a partir de esos principios no era muy distinta que la que había inaugurado el Estatuto Real ni tampoco, por tanto, la que había establecido la Carta de 1826, a imitación del constitucionalismo francés de la Restauración y de la monarquía orleanista, que a su vez había pretendido racionalizar el constitucionalismo británico, pero teniendo en cuenta sobre todo sus reglas escritas o "constitución formal" y no, o no tanto, sus convenciones o "constitución material", que desde principios del siglo XVIII habían ido apuntalando una monarquía parlamentaria, en virtud de la cual el poder regio se fue transfiriendo a un Gobierno responsable ante los Comunes y, en definitiva, hacia el electorado. Una forma de monarquía que en España no llegó a vertebrarse con la Constitución de 1845 ni con las demás que le siguieron a lo largo del siglo XIX: las de 1869 y 1876.

No quisiera terminar este recorrido por el constitucionalismo español y portugués de la primera mitad del ochocientos sin recordar - sólo eso - que durante este período se manifiestan en ambas naciones ibéricas las primeras formulaciones del constitucionalismo democrático, descontento con las transacciones constitucionales de 1837 y 1838, auspiciadas por el grueso del "progresismo" y del "setembrismo", y partidario de radicalizar el legado "doceañista" y "vintista". La Constituciones de Cádiz y de 1822 seguirían teniendo para los demócratas peninsulares un valor mítico, sobre todo la segunda, quizá por no haberse llevado a la práctica nunca. Pero el constitucionalismo democrático peninsular, tan bien representado en la segunda mitad del siglo XIX por los republicanos Emilio Castelar y Teófilo Braga, sólo tendría un breve éxito en 1873, en lo que atañe a España, mientras que en Portugal habría que esperar a 1911 para que sus propuestas cristalizasen en una Constitución.

\section{Comentario bibliografico}


Los textos constitucionales franceses citados en este estudio la declaración de derechos de 1789, la Constitución de 1791 y las Cartas de 1814 y 1830, así como la Constitución belga de 1831 pueden verse en Joaquín Varela Suanzes-Carpegna (ed). Textos Básicos de la Historia Constitucional Comparada (Madrid: Centro de Estudios Políticos y Constitucionales [CEPC], 1998). En la Introducción a este libro me extiendo sobre las diversas etapas de la historia constitucional comparada (p. XVII-XXX). Me he ocupado del constitucionalismo británico durante la primera mitad del siglo XIX en diversos trabajos, entre los que conviene ahora destacar los tres últimos capítulos de mi libro Sistema de gobierno y partidos políticos: de Locke a Park (Madrid: CEPC, 2002), cuya versión italiana publicará en 2007 la editorial Giuffrè. En lo que concierne al constitucionalismo francés, vid. mi artículo "El Liberalismo Francés después de Napoleón (de la anglofobia a la anglofilia)", na Revista de Estudios Políticos (REP), nº 76, 1992, p. 29-43.

Los textos de las Constituciones españolas que se han comentado en este trabajo - el Estatuto de Bayona, la Constitución de Cádiz, el Estatuto Real y las Constituciones de 1837 y 1845 - pueden consultarse en Diego Sevilla Andrés, Constituciones y otros proyectos políticos de España (Madrid: Editora Nacional, 1969, vol. 1). En lo que concierne a los portugueses - Constitución de 1822, Carta de 1826 y Constitución de 1838 - en Jorge Miranda, As Constituições portuguesas ( $2^{a}$ edición, Lisboa, 1984) (en donde se encuentran también las Bases da Constituição de 1822); Idem, O constitucinalismo liberal luso-brasileiro, Comissão Nacional para as Comemorações dos Descobrimentos Portugueses (Lisboa, 2001).

Sobre los Afrancesados y el Estatuto de Bayona, me he ocupado en La monarquía española entre el absolutismo y el Estado constitucional: doctrina y derecho, que se ha incluido en mi libro, de muy próxima publicación, Política y Constitución en España (1808-1978) (Madrid: CEPC, en prensa). Acerca de las Cortes de Cádiz y de la Constitución de 1812 he publicado numerosos trabajos, entre los que quisiera destacar ahora mi libro La Teoría del Estado en los orígenes del constitucionalismo hispánico (Las Cortes de Cádiz) (Madrid: CEPC, 1983), en cuyo capítulo primero me extiendo sobre las tendencias y los modelos constitucionales en esas Cortes. Una cuestión sobre la que vuelvo en El debate sobre el sistema británico de gobierno en España durante el primer tercio del siglo XIX, incluido también en el citado libro Política y Constitución en España (1808-1978). Un exhaustivo análisis sobre la organización de los poderes en esta Constitución puede verse en mi extenso artículo "Rey, Corona y Monarquía en los orígenes del 
constitucionalismo español: 1898-1814" (REP, nº 55, 1987). Examino el pensamiento constitucional de Jovellanos en "La doctrina de la Constitución Histórica: de Jovellanos a las Cortes de 1845" y el de Marina en "Tradición y Liberalismo en Martínez Marina", ambos en el citado libro Política y Constitución en España (1808-1978). Del pensamiento constitucional de Blanco-White me ocupo en "Un precursor de la monarquía parlamentaria: Blanco-White y 'El Español”" (REP, nº 79, Madrid, 1993, p. 101-120). Sobre la aplicación del código doceañista en el Trienio me extiendo en "La Monarquía imposible. La Constitución de Cádiz durante el Trienio (18201823)" (Anuario de Historia del Derecho, t. LXVI, Madrid, 1996, p. 681-687). Sobre la recepción del nuevo constitucionalismo europeo durante el Trienio, puede consultarse mi "Estudio Introductoria" a los Principios Naturales de la Moral, de la Política y de la Legislación, de Francisco Martínez Marina (Oviedo: Junta General del Principado de Asturias, 1993, 2 vol. p. I-XCII), en donde me extiendo particularmente sobre la recepción de Bentham. Este "Estudio" se recoge también en mi reciente libro Asturianos en la Política Española. Pensamiento y Acción (Oviedo: KRK ediciones, 2006).

Para el estudio de las Cortes Constituyentes de 1821-1822, vid, Benedicta Maria Duque Vieira "O problema politico no tempo das primeiras Cortes" en Miriam Halpern Pereira (dir) A crise do Antigo Regime e as Cortes Constituintes de 1821-1822: estudos e documentos (Lisboa: Sá da Costa, 1992), primero de los cinco volúmenes de que se compone esta obra. Sobre la cultura política del "vintismo" vid, asimismo, Isabel Nobre Vargues, Aprendizagem da cidadania en Portugal (1820-1823) (1997), y Maria Candida Proença, A primeira regeneração: o conceito e a experiencia nacional,1820-1823 (Lisboa: Livros Horizonte, 1990). Para el influjo de Bentham en estas Cortes, vid. Maria Helena Carvalho dos Santos, “"A mayor felicidade do mayor número'. Bentham e a Constituição portuguesa de 1822”, en Miriam Halpern Pereira et alii (coord), O liberalismo na Península Ibérica na primeira metade do seculo XIX (Lisboa: Edições João Sá da Costa editora, 1982, p. 91 y ss). Sobre la "cuestión brasileña", dentro de una amplia bibliografía, vid. Valentim Alexandre, Os Sentidos do Império, Questão Nacional e Questão Colonial na crise do Antigo Regime Portugués (Oporto: Afrontamento, 1993); y Márcia Regina Berbel, A Nação como artefatodeputados do Brasil nas Cortes portuguesas de 1821-1822 (São Paulo: Hucitec-FAPESP, 1999). En lo que atañe a la Constitución de 1822, vid. el extenso análisis comparado de Paulo Ferreira da Cunha, Para uma História Constitucional do Direito Portugués (Coimbra: Almedina, 1995), así como las páginas que le dedica 
Antonio Manuel Espanha en su reciente libro Guiando a mão invisivel. Direitos, Estado e Lei no liberalismo monarquico portugués (Coimbra: Almedina, 2004). Vid, asimismo, los comentarios sobre la la historia constitucional portuguesa de este período de dos constitucionalistas: José Joaquín Gomes Canotilho, Direito Constitucional, cap. 5 (Coimbra, 1983), y .Jorge Miranda, Manual de Direito Constitucional (Coimbra, 1988, t. 1, p. 230-247), sin olvidarse del sucinto análisis de Marcelo Caetano en Constituições Portu-

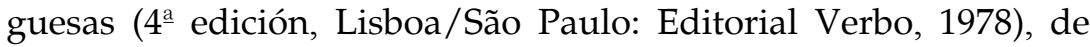
donde he extraído las citas textuales del Presidente de la Comisión Constitucional de 1821-1822. Ignacio Fernández Sarasola lleva a cabo un breve pero interesante cotejo de las Constituciones de 1812 y 1822 en "La Constitución española de 1812 y su proyección europea e Iberoamericana", en Joaquín Varela Suanzes-Carpegna (Coordinador), "Modelos Constitucionales en la historia comparada", en Fundamentos (no 2, Oviedo, 2000, p. 430-434). El texto del proyecto de Constitución de 1823, elaborado sobre todo por Ricardo Raimundo Nogueira, lo publicó Paulo Mereia en el Boletim da Faculdade de Directo (Coimbra, vol. XXIII, 196), mientras que el "Francisco Manuel Trigoso" puede verse en António Manuel Espanha, O projecto institucional do tradicionalsmo reformista: un projecto de Constituição de Francisco Manuel Trigoso de Aragão Morato (1823), en la ya mencionada obra O liberalismo na Península Ibérica na primeira metade do século XIX.

Sobre el "cartismo" y la Carta de 1826 resulta de utilidad consultar las mencionadas obras de Ferreira da Cunha, Espanha, Canotilho, Miranda y Caetano. El análisis más clásico de la Carta brasileña de 1824, su principal influjo normativo, es el de José Antonio Pimenta Bueno Direito Público Brasileiro e Análise da Constituição do Império, publicado originalmente en 1857, reeditado por el Senado Federal de Brasil en 1978 (vol. 5 de la Colección Bernardo Pereira de Vasconcelos). Un reciente, breve y didáctico análisis en Octaviano Nogueira Constituições Brasileiras (vol. 1, 1824, Senado Federal, Centro de Estudos Estrategicos, Escola de Administração Facendaria, 2a edición, Brasília, 2001). Sobre la doctrina constitucional de Constant, la autoridad más influyente en las Cartas de Brasil y Portugal, me extiendo en "La monarquía en el pensamiento de Benjamín Constant (Inglaterra como modelo)" (Revista del Centro de Estudios Constitucionales, nº 10, 1991, p. 121-138).

Analizo desde un punto de vista histórico-constitucional el exilio de 1823-1833 en "El Pensamiento Constitucional Español en el Exilio: el abandono del modelo doceañista (1823-1833)" (REP, no 87, 1995, p. 63-90), en donde recojo la cita de los "Ocios de los 
Españoles Emigrados" (traducción francesa: Les libéraux espagnols en exil: l'abandon du modèle constitutionnel de Cádiz [18231833], en Annick Lempérière, Georges Lomné, Fréderick Martinez et Denis Rolland [coord.]. L' Amerique latine et les modèles européens, Editions L'Harmattan, Maison des Pays Ibériques, Paris, 1998, p. 163-195). Braz Augusto Aquino Brancato en su interesante libro Don Pedro I de Brasil, posible Rey de España (Una conspiración liberal) (Porto Alegre: PUCRS, 1999), especialmente en su capítulo sexto, se extiende sobre el impacto de la Carta de 1826 en España y sobre los contactos entre los liberales españoles y D. Pedro IV. Un extremo este último que analiza también en Irene Castells, La utopía insurreccional del liberalismo español. Torrijos y las conspiraciones liberales de la década ominosa (Barcelona: Crítica, 1989). Sobre el pensamiento de Mouzinho da Silveira, vid. Mirian Halpern Pereira O Estado e a sociedade no pensamento de Mouzinho da Silveira (en Obras de Mouzinho da Silveira. Lisboa: Fundación Gulbenkian, t. I). Para el Estatuto Real sigue siendo imprescindible el minucioso estudio de Joaquín Tomás Villaroya El Sistema Político del Estatuto Real (1834-1836) (Madrid: Instituto de Estudios Políticos, 1968). De la aceptación y rechazo de la Constitución de Cádiz durante esta época me ocupo en mi ensayo "La Constitución de Cádiz y el Liberalismo español del siglo XIX”, que he incluido en mi citado libro Política y Constitución en España (1808-1978). Me extiendo también sobre el pensamiento constitucional de esta época en mi libro El Conde de Toreno (1786-1843). Biografía de un liberal (Madrid: Marcial Pons, 2005).

Del progresismo y de la Constitución de 1837 me he ocupado en "La Constitución Española de 1837: una Constitución transaccional", que recojo en mi mencionado libro Política y Constitución en España (1808-1978). En cuanto a la Constitución de 1838, además de los trabajos antes citados de Miranda, Espanha, Canotilho y Caetano, merece la pena consultar los trabajos de Benedicta M. Duque Vieira A revolução de Setembro e a discussão constitucional de 1837 (Lisboa: Editorial Salamandra, 1987); de Magda Piñeiro, Passos Manuel: o patriota e o seu tempo, (Oporto: Editorial Afontamento, 1996); y de Victor de Sá, A Revolução de Setembro do 1836 (3를 edición, 1978).

Sobre el restablecimiento de la Carta de 1826 en 1842 y su tercera vigencia, me remito a las ya mencionadas obras de Miranda, Canotilho y Caetano En cuanto a los principios básicos de la Constitución de 1845, puede resultar de interés mi mencionado artículo "La doctrina de la Constitución Histórica: de Jovellanos a las Cortes de 1845". 
Del constitucionalismo democrático español durante el período aquí examinado me he ocupado en la extensa Introducción, que lleva por título "Retrato de un liberal de izquierda", al libro, del que fui coordinador Alvaro Flórez Estrada. Política, Economía, Sociedad (Oviedo: Junta General del Principado de Asturias, 2004). Una introducción que he recogido en mi citado libro Asturianos en la Política Españaola. Pensamiento y Acción. Pueden consultarse también otros dos trabajos míos recientes: "El sentido moral del liberalismo democrático español a mediados del siglo XIX" y "El pueblo en el pensamiento constitucional español: 1808-1845", recogidos ambos en el citado libro Política y Constitución en España (1808-1978). En lo que concierne a Portugal, puede verse el pionero trabajo Victor de Sá A crise do liberalismo e as primeiras manifestações das ideias socialistas em Portugal (1820-1852) (Lisboa: Libros Horizonte, 1978), y el de Fernando Catroga O republicanismo em Portugal. Da formação ao 5 de Outubro de 1910 (Coimbra: Libraría Minerva, 1991, 2 vols.).

Un excelente y reciente resumen de la historiografía política portuguesa contemporánea sobre el período aquí analizado y en general sobre los siglos XIX y XX - en la que la historiografía específicamente constitucional ocupa un modesto e indiferenciado lugar - en Manuel Baioa y Paulo José Fernández "La Historia Política del Portugal Contemporáneo" (en el no 5 de la revista Historia y Política, dedicado monográficamente a "Portugal Contemporáneo" Madrid: Biblioteca Nueva, 2001/2002), en cuya página 28 reconoce este autor que en Portugal la Historia Constitucional "no ha alcanzado la mayoría de edad".

Una reciente visión comparada de la historia política española y portuguesa de este período, así como de su encuadramiento internacional, sobre todo en sus relaciones con la Gran Bretaña y Francia, puede verse en el trabajo de uno de los más relevantes lusólogos españoles, Hipólito de la Torre Gómez "Unidad y dualismo peninsular: el papel del factor externo" (en el vol. 27 de Ayer, coordinado por este autor, y titulado Portugal y España Contemporáneos, Madrid: Marcial Pons, 2000, p. 11-35). En este mismo volumen, resultan de interés los trabajos de una de las mejores especialistas en este período, Miriam Halpern Pereira "Del Antiguo Régimen al liberalismo (1807-1842)" (p. 39-64); y de Maria Manuela Tavares Ribeiro "Los Estados liberales (18341839/1890-1898)" (p. 65-95). Para una visión general de la historia portuguesa resulta muy útil, por su claridad y equilibrado criterio, el conocido manual de José Hermano Saraiva História Concisa de Portugal (Publicações Europa-America, 4ª edición, 1979). Quisiera 
reconocer también mi deuda con los libros de Hernâni Cidade Portugal Histórico-Cultural (Lisboa: Editorial Presença, 1985); de Jose Manuel Garcia História de Portugal. Uma visão global (Lisboa: Editorial Presença, 2a edición, 1983); y de Antonio Sergio Breve Intepretação da História de Portugal (Lisboa: Livraria Sá da Costa, 11ª edición, 1983).

No me gustaría terminar este comentario bibliográfico sin referirme a los clásicos y sugerentes libros de Oliveira Martins História de Portugal y Portugal Contemporáneo (ambos en Lisboa: Guimarães Editores, 1977 y 1979, respectivamente), en donde se encuentra magníficas páginas, llenas de imaginación y de capacidad evocadora, sobre el Portugal romántico, sin olvidar, claro está, su brillante História da Civilização Iberica. Por supuesto para conocer esta época resulta tan útil como sobre todo grato leer diversas obras literarias, como el ya mencionado Viagens na minha terra de Almeida Garret, así como Os Maias, de Eça de Queiroz, tan necesarios para sumergirse en el Portugal romántico como los escritos de Larra, algunas novelas de Baroja o no pocos episodios nacionales de Galdós para la España de la época. 